\title{
Preventing organised crime originating from outlaw motorcycle clubs
}

\author{
Tore Bjørgo ${ }^{1,2}$
}

Published online: 30 October 2017

(C) The Author(s) 2017. This article is an open access publication

\begin{abstract}
How can a holistic model of crime prevention be applied to crime originating from outlaw motorcycle clubs? The police in different countries and even in different police districts have varied considerably in the ways they have dealt with these outlaw $\mathrm{MC}$ clubs and the criminal activities associated with them. Some police forces have mainly applied a repressive criminal justice approach whereas others have put more emphasis on dialogue, prevention and harm reduction. This article will argue for a comprehensive approach which combines "soft" and "hard" measures, based on a holistic model of crime prevention developed in my previous works (Bjørgo 2013, 2016), based on nine preventive mechanisms. Several preventive actors beyond the police possess a variety of measures which can be implemented to activate these preventive mechanisms. Such a holistic approach reduces the need to rely on repressive approaches alone. Most of the examples in this article are from Norway and Denmark.
\end{abstract}

Keywords Crime prevention - Preventive mechanism $\cdot$ Preventive actors $\cdot$ Preventive measures · Outlaw MC clubs · Hells Angels · Bandidos · Reducing recruitment · Norms · Reducing benefits $\cdot$ Deterrence $\cdot$ Disrupting crime $\cdot$ Incapasitation $\cdot$ Reducing opportunities for crime $\cdot$ Harm reduction $\cdot$ Exit

This article ${ }^{1}$ will discuss how a holistic model of crime prevention can be applied to crime originating from motorcycle clubs such as the Hells Angels, Bandidos, Outlaws,

\footnotetext{
${ }^{1}$ A previous version of this article was originally published as a chapter in my book Preventing Crime: A Holistic Approach (Bjørgo 2016). The book presented a general model of crime prevention which, to demonstrate its applicability, was applied to five very different forms of crime: burglary, criminal youth gangs, driving under the influence of alcohol or drugs, organised crime emerging from outlaw MC gangs, and terrorism.
}

\section{Tore Bjørgo}

tore.bjorgo@c-rex.uio.no; http://www.uio.no/c-rex/english/

1 Norwegian Police University College, P.o.box 5027, Majorstuen, 0301 Oslo, Norway

2 C-REX, University of Oslo, P.o.box 1097, Blindern, 0317 Oslo, Norway 
Mongols MC and Coffin Cheaters, commonly referred to as "outlaw motorcycle gangs" or "1\%er clubs". These clubs may be seen as examples of how an oppositional subculture can develop in the direction of providing a basis for criminal activities, and in many cases, for organised crime. However, the extent to which these clubs are criminal organisations in the strict sense of the term is highly disputed (Lauchs et al. 2015; Barker 2007). The degree to which the clubs are involved in organised crime also varies greatly. In some countries these outlaw MC clubs nevertheless constitute major crime problems in terms of armed conflicts, shoot-outs and bombings in public spaces and heavy involvement in various criminal activities.

The police in different countries and even in different police districts have varied considerably in the ways they have dealt with these outlaw MC clubs and the criminal activities associated with them. Some police forces have mainly applied a repressive criminal justice approach whereas others have put more emphasis on dialogue, prevention and harm reduction. This article will argue for a comprehensive approach which combines "soft" and "hard" measures, based on a holistic model of crime prevention developed in my previous works (Bjørgo 2013, 2016). Such a holistic approach reduces the need to rely on repressive approaches alone. Most of the examples in this article are from Norway and Denmark.

\section{A holistic model of crime prevention}

Several models exist for crime prevention. ${ }^{2}$ These models overlap to some extent, but also appear to a great degree to be competing ways of thinking. Since they have very different theoretical bases and concerns, they can to some extent appear incompatible, both theoretically and practically.

The criminal justice crime prevention model is based on the preventive effects of punishment. In its simple form it differentiates between "individual prevention" and "general prevention". Laws set norms about unacceptable behaviour, bolstered by the threat of punishment: Specific deterrence against those who directly feel the consequences of breaking the laws, and general deterrence against those who see that others are punished. Prison is also used to incapacitate offenders for some time.

The social crime prevention model attempts to influence the conditions that make people criminals or get them involved in crime, addressing risk factors as well as protective factors. Social prevention measures can be introduced at a societal level (macro), group level (meso) or individual (micro) level.

The situational crime prevention model aims to change those situations in which criminal acts occur and to remove opportunities for crime. Measures can be introduced in order to a) increase the effort necessary to carry out a specific criminal act; b) increase the risk of being detected and stopped; c) reduce the benefits from a specific criminal act; d) reduce provocations that could trigger a specific criminal act; and e) remove excuses for committing the criminal act (Clarke 1997).

These three models of crime prevention all provide important insights. They do not fit well together, however, and separately they are too narrow. By extracting the key

\footnotetext{
${ }^{2}$ For a more detailed discussion of different models of crime prevention and the nine preventive mechanisms, see Bjørgo 2016, chapter 1.
} 
preventive elements of these three approaches a more holistic model of crime prevention can be constructed, using preventive mechanism as the basic principle. On this basis we can identify at least nine different, general prevention mechanisms that can be applied to all forms of crime:

- Reducing recruitment to criminal activities and groups

- Establishing and maintaining normative barriers against crime

- Deterring crime

- Disrupting attempts to commit crime

- Reducing opportunities for crime and protecting vulnerable targets

- Reducing rewards and benefits of crime

- Reducing harm from crime

- Incapacitating criminal actors

- Desistance and rehabilitation of criminals

Preventive mechanisms are simple theoretical explanations of how a measure is causing an effect, in this case, reducing crime. Some mechanisms are mental, such as deterrence, whereas others are more physical and observable, like incapacitation (e.g. through the use of incarceration or handcuffs). Measures are the means or methods implemented to activate a mechanism in order to achieve a specific outcome. A measure (e.g. arresting someone) may activate several different mechanisms, but also unintended mechanisms (side-effects). Different measures may also be used to activate the same mechanism.

To develop the general model of crime prevention into a strategy for crime prevention it must be concretised with regard to specific types of crime, such as varieties of organised crime. Each of the nine mechanisms must thus be specified and described for the actual crime problem:

- How do the various preventive mechanisms work to reduce a specific crime problem?

- Which measures or methods can be used to activate these mechanisms?

- Who are the principal actors in the implementation of the various methods?

- Who are the target groups for the various strategies and their relevant measures?

- What are the strengths and the positive side effects of the various measures?

- What are the limitations, costs and negative side effects of the various measures?

A more extensive explanation and discussion of this holistic model of crime prevention is provided in my two recent books (Bjørgo 2013, 2016). The basic argument is that a holistic approach, making use of all nine mechanisms and their relevant measures will be more effective in reducing crime than relying on a few mechanisms and measures, and will also make it possible to be less heavy-handed with repressive measures.

In the following, this generic model will be applied to crime in the form of organised crime originating from outlaw MC clubs.

\section{On organised crime and outlaw motorcycle gangs}

What constitutes organised crime, or how it should be defined, is a subject of intense debate (Korsell and Larsson 2011; Beare 2003; Edwards and Gill 2003). Part of the 
disagreement concerns whether organised crime is a phenomenon that should be defined on the basis of what characterises criminal organisations or what characterises organised criminals and their illegal activities. Taking the latter perspective as our starting point, we can at least say that it involves profit-oriented criminal activities with multiple participants who collaborate over time based on a degree of structure and role allocation.

The Hells Angels are regarded as the original outlaw club that provided the template for all the others, even though the Outlaws (another MC club) were founded earlier. The outlaw biker subculture emerged on the West Coast of the USA at the end of the 1940s. It consisted of bikers who refused to register with the mainstream organisations for motorcyclists and submit to their rules (including complying with traffic rules). After the first biker riot in Hollister, California on 4 July 1947, they were described as "the 1 per cent deviant fringe" in motorcycle circles, a label outlaw bikers adopted as a badge of honour. Many had " $1 \%$ " tattooed on their body or wore it as a patch on their vest. ${ }^{3}$ In other words, they defined themselves in contrast to the "tamed" mainstream bikers, "the 99 per centers". Instead, they cultivated an image of being rebels and outlaws who were living out their notion of freedom. Living by your own rules and defying conventional society's norms and regulations became a key part of outlaw biker identity.

The degree to which individual members and the clubs are involved in organised crime also varies greatly. For example, Danish and Swedish outlaw motorcycle clubs are generally more heavily involved in organised crime than the majority of their Norwegian "brothers", and the level of violence has historically been much higher (Rigspolitiet 2014; Politidirektoratet 2014). For many of the participants this meant simply not caring about speed limits and bans on marijuana, offences that have more to do with lifestyle than crime for profit. But a large proportion of the members of outlaw biker clubs such as the Hells Angels, Bandidos and their prospects and support clubs have been involved in serious crime such as aggravated theft, smuggling and selling drugs (especially (meth)amphetamine and hashish/marijuana), illegal debt collection, money laundering and so on. In 2012, the Norwegian National Criminal Investigation Service (NCIS, KRIPOS in Norwegian) conducted an analysis of the criminal activities of the Hells Angels in Norway. At the time, the Hells Angels had 115 members and prospects, and 60 participants in the club's support groups: a total of 175 people. Of these 175 people, 121 (i.e. 69\%) had 409 prior convictions between them. ${ }^{4}$ The most frequent occurring crime types were aggravated theft, drug crimes and violence. However, many of these convictions have nothing or little to do with their membership of Hells Angels or organised crime activities, and much occurred a long time ago. Most of the drug convictions are about consumption and possession of drugs rather than about smuggling and selling drugs. ${ }^{5}$

\footnotetext{
${ }^{3}$ The almost mystical origin story of the outlaw biker subculture is vividly described and analysed in Daniel Wolf's excellent monograph about a Canadian outlaw biker club, The Rebels (Wolf 1991: 4-8).

${ }^{4}$ More detailed figures from the survey can be found in the Norwegian National Police Directorate report for 2014, pp. 17-18. 62\% of Bandidos' members had prior convictions and 56\% of the members of the Coffin Cheaters had prior convictions (source: the magazine Norsk Politi, no. 2, 2012).

${ }^{5}$ My colleague, professor Paul Larsson (Norwegian Police University College), was highly critical to the ways KRIPOS (the National Criminal Investigation Service of Norway) presented the statistics of the HA members' criminal records when he was an expert witness in a trial against Hells Angels Oslo in Oslo District Court during spring 2014.
} 
However, this also means that a significant proportion of the individual members do not appear to be involved in criminal activities, or at least that any involvement on their part is very limited. ${ }^{6}$ The degree to which members are involved in criminal activities can also vary greatly between different chapters of the same club. In some local chapters, few or none of the members have any criminal record. This makes it difficult to equate membership of an outlaw motorcycle club with participation in (organised) crime.

Even though outlaw motorcycle clubs are some of the most hierarchical and formalised organisations that can be found within criminal milieux, it has proved impossible under Norwegian legislation to secure a court judgement against these clubs stating that they are criminal organisations, despite several attempts. However, there have been several major drugs cases in which the "Mafia paragraph" in the Norwegian General Civil Penal Code (section 60a) has been used against central members of outlaw motorcycle clubs. ${ }^{7}$ In these cases, the central roles played by the clubs have been drawn in more indirectly:

This structure [in the Hells Angels club] can be found in the organised criminal group, and the internal allocation of roles in the group mirrors, in the opinion of the Court of Appeals, the allocation of roles in the Hells Angels of the accused who are linked to the club. ${ }^{8}$

However, while a large number of members and leaders have been convicted, the police have generally found it difficult to prove that the clubs themselves are directly involved in criminal projects. The exceptions to this rule are that courts in some German federal states, Australia and Canada have found the Hells Angels to be criminal associations. ${ }^{9}$ The typical pattern is that individual members carry out criminal projects together with partners from inside or outside the club. This network, consisting of people who believe

\footnotetext{
${ }^{6}$ As Decker and Pyrooz (2015: 108) put it, "not all gang members are criminals, and not all criminals are gang members. That is, we know a lot about how rates of criminal behavior are higher between gang and non-gang populations as well as how this behavior changes upon entering and existing gangs. Yet little is known about distinguishing high-rate gang offenders from low-rate gang (and from non-) offenders."

${ }^{7}$ Section 60a of the Norwegian General Civil Penal Code: "If a criminal act has been committed as part of the activities of an organised criminal group, the maximum penalty laid down in the penal provision shall be increased to double its prescribed limit, but not by more than five years' imprisonment. An organised criminal group is here defined as a collaboration between three or more persons having as a main purpose the committing of an act that is punishable by imprisonment for at least three years, or that is based on an not insignificant part of its activities consisting of committing such acts." The wording of the provision was amended in June 2013 to make it easier to apply it against organised crime of a more network-based nature. ${ }^{8}$ Translated from a quote from the judgement against Hells Angels members in Hålogaland Court of Appeals, 5 December 2013. The subsequent appeal was rejected by the Supreme Court of Norway.

${ }^{9}$ However, even in these countries, some of the verdicts have been overturned in higher courts. In Germany, there are two different legal tracks on which biker clubs can be outlawed, one is under criminal law the other under administrative law. Under criminal law members of a biker club can be found to constitute a criminal association ( $§ 129$ Penal Code), which led to the disbanding of the Hamburg Hells Angels charter. Under administrative law, an association is prohibited with the consequence that the assets of the association are seized and attempts to continue the same association are forbidden. This has also happened in the case of some Hells Angels charters in Germany. Other charters have dissolved voluntarily to avoid having their assets seized. In a new development, the death head symbol of Hells Angels is now also considered the insignia of a criminal association and therefore wearing or displaying it constitutes an offence in itself. See the German magazine Stern, 1 August 2014, http:/www.stern.de/panorama/hells-angels-abzeichen-altes-verbot-in-neuemzeitgeist-2127780.html (accessed 27.01.2016).
} 
themselves to be outside the law, makes it easier for individual members to commit crimes and get away with them. The Hells Angels and other outlaw clubs have been described by some observers as organisations for criminals rather than criminal organisations (Lavigne 1996: 246-7). Nonetheless, it is important to note that not all members of these clubs are personally involved in crime, although they obviously tolerate others' involvement.

There are aspects of these outlaw motorcycle clubs that make them highly suitable as a base for criminal activities (Wolf 1991: 265-270). The closed brotherhood and wall of secrecy ensure security. Norms concerning solidarity and strict internal justice mean that informing the police or testifying in court against other bikers (or criminals in general) are rare. Their violent image also tends to intimidate others into silence (Barker 2005, 2011; Lauchs et al. 2015). On the other hand, the fact that their visibility and provocative behaviour attract the attention of the police can be a disadvantage.

In Scandinavia, the international outlaw motorcycle clubs established themselves first in Denmark during the 1980s, and then during the early 1990s rapidly spread to Norway and Sweden.

As such, the Bandidos MC and Hells Angels have dominated the Swedish gang landscape for over 10 years and have become a "role model" for other criminal networks trying to form an organizational platform. In many respects, these outlaw motorcycle gangs have been the backbone of what we today would consider organized crime in Sweden. Many groups have tried to "copycat" their structure. For example, it was popular and fashionable among criminal networks to have a "business interaction" with the motorcycle gangs as it produced "status" and a sense of criminal legitimacy. Consequently, doing business with Hells Angels or Bandidos MC was something that many criminal networks wanted. Therefore, criminal networks actively sought to establish relationships with the outlaw motorcycle gangs. (Rostami and Leinfelt 2012: 254)

It has also been claimed, especially by the police, that their territorial orientation of the outlaw MC gangs enabled them to control certain forms of criminal activity within their territory. The police usually interpreted the "Great Nordic Biker War" from 1995 to 1997 as primarily a struggle between organised criminal groups for control of criminal markets. This was probably a somewhat oversimplified interpretation. While the Hells Angels and Bandidos undoubtedly fought for territorial dominance and control, there was little to indicate that they were, for example, trying to monopolise the amphetamine market by attempting to squeeze out other criminal groups consisting of people with ethnic minority backgrounds. The territorial mindset appears to be first and foremost motivated by living up to the subculture's values, and not primarily based on a desire for financial profit. The conflict was more about power, politics and intangible values than a struggle for criminal markets. The Bandidos refused to submit to the Hells Angels' demand to be the dominant outlaw motorcycle club because they were the oldest and largest. For their part, the Hells Angels accused the Bandidos of breaching some of the subculture's common rules, including admitting members who had previously been thrown out of the Hells Angels in "bad standing". The dispute between the two clubs broke out into armed conflict in which firearms, anti-tank missiles and car bombs were used. Twelve people were killed and at least 70 were wounded, including 
several outsiders. The car bombing of the Bandidos' clubhouse in the Norwegian city of Drammen on 4 June 1997 killed a random passer-by and caused at least NOK 500 million (approximately USD 70 million) of property damage. A new gang war started in Denmark in 2008, with the Hells Angels and their support group AK81 on one side and various immigrant gangs on the other. There have also been violent conflicts between different outlaw motorcycle clubs and their support groups in Denmark: 232 shootings in public were registered in the five years from 2009 to 2013, with 18 killed and 198 wounded. ${ }^{10}$ A number of the wounded were random passers-by with no links to any of the gangs. Since 2012, the level of conflict in Sweden has also increased between the Hells Angels and Outlaws, and between the Bandidos and Mongols MC, with murders and a number of attempted murders. In Germany, there has been an ongoing "rocker war" between Hells Angels and Bandidos since 2009. In Quebec, Canada, a biker war raged between 1994 and 2002, costing more than 150 lives, including innocent bystanders. Nine were killed and 18 wounded in a shootout between several outlaw biker gangs in Waco, Texas in 2015. Similar biker wars have occurred in the USA, UK, Australia and elsewhere. Meanwhile, in Norway, the situation between the Hells Angels, Bandidos and other gangs has been fairly peaceful since the "Great Nordic Biker War" ended in 1997. But the potential for violent conflict still remains, not least because new clubs such as the Gladiators and Mongols are establishing themselves in Norway and challenging the dominance of the Hells Angels.

There are good reasons for preventing the outbreak of new violent conflicts of this sort, as well as the serious crime that follows in the wake of many outlaw motorcycle clubs. The criminally oriented clubs constitute an organisational and cultural infrastructure for serious, lasting and extensive crime committed by a substantial proportion of a club's members and supporters (Politidirektoratet 2014: 6-12). The conflicts involving the clubs have also sometimes caused a heightened sense of insecurity in surrounding communities and have had substantial negative ripple effects.

However, how far the police and other prevention actors can, and should, go to combat outlaw motorcycle clubs and whether they can all be lumped together, presents some dilemmas. Should they only be prosecuted for the crime they actually commit, or should they also be combated because of what they are, in that they position themselves outside the law and follow their own brutal rules for conflict resolution and domination?

The following discussion will demonstrate how the nine preventive mechanisms can be applied to organised crime originating from outlaw MC clubs. A holistic approach involving many preventive actors with a diversity of measures at their disposal may have greater impact than relying on criminal justice measures alone.

\section{Reducing recruitment to outlaw motorcycle gangs}

Unlike most other gangs, the Hells Angels, Bandidos and majority of other outlaw motorcycle clubs have set procedures for becoming a member, and formal hierarchies

\footnotetext{
${ }^{10}$ The figures are based on annual "biker and gang crime" reports from the Danish National Police for the period 2009-2013. These annual reports only contain precise figures for the current year, while figures for previous years are only provided in graphic form. Investigations may have subsequently resulted in the assessment of some cases changing, meaning that the comparison figures will not be totally precise.
} 
and organisational structures with defined roles and positions. "Hang arounds" must, through their actions and behaviour, prove that they are worthy of being made official club prospects, but are allowed to participate in club parties. Their status may be upgraded to "Associate". "Prospects" are official prospective members who are allowed to wear the club's vest and patches. As they make their way up the hierarchy, they must perform services for the club and full members, which may also include doing criminal spadework to qualify. It is these bottom levels that are responsible for carrying out most of the actual crime and violence, while full members are often the masterminds who reap the profits. In recent years, the Hells Angels, Bandidos and Outlaws have established ties with criminal youth milieux as support groups, which includes wearing T-shirts with logos such as "AK81" (which stands for the Norwegian slogan meaning "Always Ready Hells Angels") and "Red and White Crews" on them; the Bandidos have their "Support X-Team", while the Outlaws have their "Black and White Crew". The participants often have backgrounds from serious crime and bodybuilding/martial arts milieux, but they usually do not ride motorcycles. It appears these support groups are established in order to create a certain distance between the outlaw motorcycle clubs and those who carry out the violence and crime. ${ }^{11}$ At the same time, it is likely that participation in these support groups may be a recruitment pathway into membership of the clubs. It is worth noting that while the participants in these support groups are often relatively young (typically around 20), full members of the outlaw motorcycle clubs are usually mature adults (30-50). Some of them probably feel too old to fight, so they leave the actual violence to younger people.

The Hells Angels in Norway have also built up a network of so-called "diamond" support clubs that officially support the Hells Angels and can wear a diamond patch (bearing the number 81 , which means "HA") on their vest. The degree to which these diamond support clubs and their members are involved in crime varies. In addition to this, the Hells Angels have, based on a Swedish model, tried to introduce the so-called "Norway model" for coordinating Harley Davidson clubs across the country regardless of any expressed or unexpressed support of outlaw motorcycle clubs. The Bandidos and other outlaw motorcycle clubs are also part of this, along with a large number of law-abiding motorcycle clubs, totalling around 100 in 2014. The "Norway model" involves giving the Hells Angels control over which motorcycle clubs can wear a threepiece back patch, so-called "colours", in Norway. The Hells Angels have assigned themselves responsibility for administering three-piece back patches. Those clubs that try to ride wearing a back patch without submitting to the Hells Angel's "Norway model" are sanctioned (Politidirektoratet 2014:16). The "Norway model" is thus an obvious strategy aimed at ensuring the Hells Angels' dominance and influence over the wider motorcycling community.

On a collective basis, therefore, there are numerous levels of links to the outlaw motorcycle clubs. At the top level are the established international outlaw motorcycle clubs and clubs in the process of becoming members of one of these. On the next level down are clubs, crews and groups that officially support an outlaw motorcycle club,

\footnotetext{
11 The organisational structure of the outlaw motorcycle clubs is described in the Norwegian Ministry of Justice's Report to the Storting No. 7 (2010-2011) The Fight against Organised Crime, pp. 64-68. http://www.regjeringen.no/nb/dep/jd/dok/regpubl/stmeld/2010-2011/meld-st-7-20102011/4/8. html?id=629186 (accessed 27.01.2016). Also see the Norwegian National Police Directorate report (Politidirektoratet 2014: 16-17) for a description of the role of "street crews".
} 
such as the Hells Angels' diamond support clubs and equivalent support clubs and "crews" of other clubs. The clubs with the weakest links are the numerous clubs that participate in the "Norway model" without wishing to define themselves as an outlaw motorcycle club, but which nonetheless submit, to some degree, to the dominance of the Hells Angels.

A Danish survey of longitudinal register data (Klement et al. 2010) showed that joining a "biker gang" (i.e. an outlaw motorcycle club or support club) or other gangs resulted in people committing significantly more crime. The member's criminality increased both in scope and seriousness in the two years after joining the gang compared with the two years before joining.

The growth in crime particularly involves violations of the Danish penal code's provisions on drugs $(+100$ per cent), firearms $(+72$ per cent) and violence $(+72$ per cent), while the growth in property crime was modest. [...] It is thus apparent that the growth in crime is especially high among members of the biker groups the Hells Angels and AK81. (Klement et al. 2010: 98)

This rise in participating in criminal activities therefore provides a compelling reason for trying to reduce recruitment to these groups.

On an individual level, the prevention mechanism involves disrupting any recruitment process as early as possible in order to prevent people rising in the hierarchy and committing acts that bind them closer to the criminal milieu. People who have a strong desire to become full members of the Hells Angels or one of the other clubs can often be more easily manipulated into committing criminal acts in order to improve their status and ties with a club. On a group level, one objective should be to prevent motorcycle clubs taking the step from being an "outlaw" club to being admitted to one of the outlaw motorcycle clubs, or becoming an official support club. Another goal may be to prevent the Hells Angels expanding and consolidating their power and influence over the broader motorcycling community through their control of the "Norway model" or similar strategies elsewhere to bolster the Hells Angels' dominance.

The measures for preventing recruitment largely involve carrying out wide-ranging social prevention work with children and young people in general to help ensure that as many as possible become well-integrated citizens (universal prevention), ${ }^{12}$ as well as more individually targeted measures (selective prevention) aimed at catching those who are developing problem behaviour and becoming involved in crime. Danish surveys show that a large proportion of "bikers" (i.e. members of outlaw motorcycle clubs) have been exposed to a number of risk factors during their upbringing that make them vulnerable to ending up with criminal careers (Klement et al. 2010). Biker gang members have often lost out educationally and socially, although this is by no means true for all of them. ${ }^{13}$ The most effective measure for hindering recruitment into criminal activities is probably putting in place a combination of social integration measures and a graduated system of sanctions for problem behaviour and involvement

\footnotetext{
${ }^{12}$ In the following, I will use the newer terms universal, selective and indicated prevention rather than the older terms primary, secondary and tertiary prevention.

${ }^{13}$ A Danish study shows that every second member of a "biker gang" ended up as a social welfare recipient. http://www.bt.dk/krimi/hver-anden-rocker-er-paa-offentlig-forsoergelse (accessed 15 February 2013).
} 
in outlaw motorcycle clubs. Early intervention with children and young people growing up in deprived conditions is of course preferable to preventing the development of problem behaviour at a later stage. However, social prevention measures can also work well, even in the case of young people who have become involved in offending and other forms of problematic behaviour. These could involve helping with school, work, personal problems or offering alternative activities. One example from Norway of a targeted local authority measure is the "follow-up service", which is aimed at young people without an offer of a school place or who are in the process of dropping out of upper secondary education. The goal is to get them back into education or into full-time work. One common measure used by the police in Scandinavia is the preventive dialogue (also called conversation intervention or empowerment conversation), where the police invite young people whom they believe are starting to develop problem behaviour to the police station to talk to them, preferably with their parents (see Bjørgo 2016:90). Another frequently used measure is to create tailored programmes through inter-agency partnerships. ${ }^{14}$ These aim to follow up individual young people to prevent them from slipping into more serious crime. One promising measure in Norway is the so-called "follow-up teams for young offenders". This is a tailored package of measures created for criminally active young people in which participation in positive and inclusive activities is an alternative to punishment. ${ }^{15}$

A number of more informal measures may also help prevent recruitment. Appeals by family members or girlfriends to stay away from the outlaw motorcycle clubs may presumably have some effect (Kennedy 2009: 182-5). Other measures such as warnings and negative social or criminal sanctions may have a deterrent effect (more about this later). In some cases, it may also be possible to undermine a potential recruit's "criminal standing" with, and usefulness to, an outlaw motorcycle club, for example by the police frequently talking to them in public, which may cause their reliability to be questioned by club members. More generally, information about the negative aspects of gang life may help lessen the attraction of outlaw motorcycle clubs. In some cases, disillusioned former members of the Hells Angels and Bandidos have come forward and spoken about the cynicism and brutality in the milieu, and the physical and psychological costs. ${ }^{16}$ It is known that the prospects of some outlaw motorcycle clubs are tasked with recruiting support groups (e.g. AK81). Ensuring the failure of these "recruiting officers" will have a double effect: it will undermine their careers in the club and stop them managing to recruit others into criminal activities or as supporters.

As mentioned, the Hells Angels in Norway have tried to build up a network of socalled diamond support clubs whose members are often not particularly involved in crime. However, there is a significant risk that they may be drawn into criminal

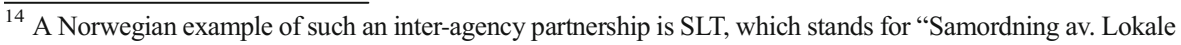
Tiltak" (Coordination of Local Measures). SLT partnerships were established in around 200 of Norway's 429 local authorities in 2012. The scheme involves the police and various local authority agencies working together to prevent youth crime, often with a view to following up individual young people and problem youth milieux. A similar scheme in Denmark is called SSP (School, Social services and Police). See Bjørgo (2016: 247-8) for more details.

${ }^{15}$ This and other measures are described in more detail in Bjørgo (2016, Chapter 3).

${ }^{16}$ Several books have been (co)authored by former members of outlaw motorcycle clubs, such as Pat Matter and Chris Omodt (2014). Breaking the Code: A True Story by a Hells Angel President and the Cop Who Pursued Him; and Wierup and Olson (2012). Helvetet inifrån - femton år i Sveriges största brottsorganisation (The hell from within: fifteen years in Sweden's largest criminal organisation).
} 
activities and they could easily become part of the power struggle in a conflict between the big outlaw motorcycle clubs. Besides this, there have been several examples where such friendly clubs have risen through the ranks and become more heavily involved in shady activities. A number of local authorities and police forces have therefore focused heavily on getting such diamond support clubs to withdraw their support for the Hells Angels. It means a lot when law-abiding motorcycle clubs mark the difference between them and the criminal clubs. The significance of this is indicated by the importance outlaw motorcycle clubs themselves attach to having the support of other clubs and exerting their influence over the broader motorcycling community.

In other words, a number of different actors have various measures for reducing recruitment to outlaw motorcycle clubs at their disposal. These include youth workers, schools, the police, politicians, the media, civil society, families/girlfriends and lawabiding motorcycle clubs. The target groups are first and foremost children and young people, with the aim being to prevent social marginalisation and subsequent involvement in criminal careers (prevention). However, special attention should also be paid to individuals and motorcycle clubs that are at risk of being recruited as prospects or supporters of outlaw motorcycle clubs. It is important to prevent vulnerable people ending up in prison as a result of criminal tasks delegated to them. In other words, the target groups are both entire population groups (universal prevention) and risk groups (selective prevention), but particularly the latter.

The benefits of social integration measures are that they can have a range of positive ripple effects beyond preventing crime. Universal prevention measures should therefore also be justified by the fact that they are intended to ensure children and young people have good lives and become positive citizens, while reduced crime is a positive side effect. In particular, more individually targeted prevention measures must be aimed at those who are at risk of dropping out of society and into a life of crime.

At the same time, these sorts of prevention efforts can have limitations and side effects. Subjecting people and groups to sanctions simply because they may commit crimes in the future can be problematic (Tilley 2009: 27). Pressure and accusations can push people and groups further into a criminal milieu and lead to further ostracism and stigmatisation. There is a real danger that some sanctions will impact innocent people. At the same time, it is difficult to find relevant positive social prevention measures that can be used in relation to adults, which is what outlaw biker milieux mainly consist of.

\section{Establishing norms against the acceptance of outlaw motorcycle gangs}

It is a paradox that outlaw motorcycle clubs claim that they are not part of society and do not care what others think of them, and yet the Hells Angels and, to some extent, the Bandidos are still active on the public relations front. In some contexts they want to maintain their reputation as a dangerous group that no one goes up against unpunished, especially in relation to competing motorcycle clubs and criminal milieux. In these circumstances they come across as aggressive "grizzly bears", while in other contexts it is more opportune to appear to be kind and harmless "teddy bears". They arrange open days for families to show they are friendly, innocent guys who are just interested in motorcycles and comradeship. It is therefore obvious that outlaw motorcycle clubs feel vulnerable when it comes to how the general public views them. They often react 
sharply if the police or others call them criminal clubs. They seek (and sometimes get) local support and sympathy because they believe they have been discriminated against by the police and local authorities. These reactions indicate that establishing norms against membership and involvement in the activities of outlaw motorcycle gangs, and refusing them the legitimacy they so obviously desire, is an important prevention mechanism.

A range of potential measures are available here. Legislation can ensure that some legal constraints are set with respect to what these groups can do. For example, the Norwegian Banking Law Commission helped to strengthen the criteria for obtaining a licence to run a legal debt collection agency. This made it harder for motorcycle gangs to buy up debt cheaply and then exploit their intimidating reputation to collect it (Barker 2011). Local authorities and local politicians can make it clear through public statements that outlaw motorcycle clubs are not wanted in their local community. The general public can reinforce informal social sanctions by showing they want nothing to do with outlaw motorcycle clubs, for example by not attending the clubs' open days for families. Even more importantly, local business people and civil servants should not participate in parties and similar events arranged by the outlaw clubs. Part of the reason for this is that it is important not to legitimise the clubs, but it is even more important that they do not put themselves in compromising situations that could later be used to blackmail them; for example, being very drunk, being present when hashish was being smoked or being in the company of skimpily dressed women, so-called "honey traps". There have been a number of instances in which local politicians, local authority civil servants or business people have been photographed in similar compromising situations. In one case, a mayor of a Norwegian town experienced major credibility problems because a local newspaper published a photograph of her wearing a Bandidos jersey with the text "Support for the local Fat Mexican" (another name for Bandidos). ${ }^{17}$ It is also important to demonstrate that it is unacceptable for local business to use the clubs' criminal services, for example debt collection or protection and security services. Similarly, the local community should be made aware that they are supporting organised crime if they buy hashish. Local and national media play a key role in how outlaw motorcycle clubs are perceived and can also act as important forums for debate and expressing opinions.

In other words, there are many actors who can make a contribution here. Local politicians can play a key role as leaders and opinion formers. In a number of local authorities mayors have led the fight against the Hells Angels and other outlaw motorcycle clubs that are establishing a presence and carrying out their activities in the local authority. In some cases they have been subjected to threats and physical reprisals for their resistance. Therefore, it is important that those who lead the resistance have strong support behind them from other local politicians, the police, the media, business and civil society. Parents and schools are important when it comes to influencing the attitudes of young people. Another very important factor can be the encouragement of young women not to attend parties with the "baddest boys", where they run a real risk of being taken advantage of and abused. Outlaw motorcycle clubs generally have a degrading view of women as objects for their use and the "club's property",

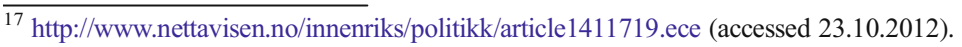


especially in the case of those who do not have a permanent and established relationship with one of the members.

This strategy of building normative barriers has a number of target groups. It can be aimed at the local community and local businesses to get them to keep their distance from outlaw motorcycle clubs and their activities, and to get club members' social circles to signal what they think of their association (universal prevention). Potential members of outlaw motorcycle gangs, both individuals and potential support clubs, must hear that they are crossing a moral boundary if they associate themselves with an outlaw biker club. Similarly, potential users of criminal services, especially debt collection services and hashish buyers, must clearly get the message to think again (selective prevention).

The benefits of a normative prevention strategy are that most of the measures are generally democratic, not particularly repressive and relatively uncontroversial, while also being inexpensive. Outlaw motorcycle clubs promote themselves as being outlaws. The challenge is to show that law and society's rules and norms apply to them as well.

The drawbacks and side effects are that it can be difficult to influence the most hardened, while it may be easier to reach their wider social circles. Awareness campaigns may have a tendency to come across as propaganda. There is also a real danger of moral condemnation contributing to the stigmatisation, criminalisation and further social ostracism of people who have already been marginalised. Given their lifestyles, criminal activities and open rejection of society's norms, outlaw motorcycle clubs are prone to becoming a "good enemy" that can provide a basis for moral panic (Cohen 1973). Intimidating reputations can easily be created that are not always rooted in reality.

\section{Deterring people by raising the cost of participating in gangs and criminal activities}

The prevention mechanism involves increasing the cost of participating in criminal activities and outlaw motorcycle gangs through threats of punishment or informal social sanctions. More generally it can involve "making life hard for them" so that membership in an outlaw motorcycle club becomes less attractive, which in turn can reduce someone's motivation to participate in both the club and criminal activities.

Possible measures include both traditional criminal sanctions, the loss of rights and more informal social sanctions. Prosecution for criminal acts is a main police strategy against the outlaw biker groups. Among the statistics the Danish National Police publish in their annual reports (2009-2013) on their efforts against "biker and gang crime" are how many years in prison members of biker clubs and gangs are sentenced to. Some of the figures do not differentiate between outlaw biker clubs (i.e. the Hells Angels, Bandidos and their support clubs) and other (generally ethnic minority) gangs, but the biker groups account for 741 of the 1040 registered people in the level 1 groups. ${ }^{18}$

\footnotetext{
${ }^{18}$ Level 2 refers to groups that have looser ties to "biker clubs and gangs". Levels 1 and 2 are defined on p. 7 of "Rockere og bander 2012" (Rigspolitiet 2013) https:/www.politi.dk/NR/rdonlyres/A80FE0FB-894C-45 D2-A408-2D9D525A1ECB/0/rockerbanderappport2012.pdf.
} 
The 1,040 people who at the beginning of January 2013 were associated with the level 1 groups, including both biker clubs and gangs, were charged 3,541 times for related crimes in 2012. [... This] group of people had 2,429 convictions recorded against them for related crimes in 2012. [...] They were sentenced to combined total of around 377 years in 2012 for all the criminal offences committed. In total these people [during their criminal careers] have been sentenced to 3,473 years in prison for all the criminal offences they have committed. ${ }^{19}$

The extensive use of imprisonment is obviously one of the most important measures the police use to combat criminal outlaw motorcycle clubs in Denmark, Norway and other countries in which these groups are active. Imprisonment is used both as a deterrent and as a means of incapacitation.

In addition to applying measures under criminal law, the police can also extensively check and frisk the milieu around an outlaw motorcycle club, refuse foreign visitors entry to the country and implement other measures that can interfere with and spoil the milieu's activities. People who go to parties at outlaw motorcycle clubs also risk being searched by the police. In the long term, such measures can make participating in this milieu less attractive. If a motorcycle club chooses to become a "diamond support club" that publicly supports the Hells Angels (or the equivalent for the other outlaw motorcycle clubs), or tries to become a full member, the police will probably make them aware of the consequences that such an association will have when it comes to the attention they will receive from the police and the resulting control measures. ${ }^{20}$

However, imprisonment and police attention are just two of the many possible sanctions that may be deterrents for members of outlaw motorcycle clubs. The loss of various rights may have just as strong a deterrent effect on some people. For some the loss of security clearances, licences for hunting weapons, driver's licences or licences to sell alcohol can hurt just as much as a few months in prison. If a person has a criminal record or misuses intoxicants, the police can both refuse firearm licences and revoke licences for driving cars and motorcycles. All non-American Hells Angels and Bandidos members are banned from entering the USA, ${ }^{21}$ which probably also feels like quite a dramatic sanction since the mother organisations are, after all, American.

In a number of cases the Hells Angels and other motorcycle clubs with criminal reputations have succeeded in recruiting personnel with firearms training and other special skills from the armed forces. In Norway, this included a gunsmith who was exposed when he repaired a stolen automatic weapon in an Armed Forces' weapons workshop. When it was learned that he had close ties with the Hells Angels, he lost his security clearance and job in the Armed Forces, and was also convicted of weapon theft, among other things. However, following this he was admitted as a full member of the Hells Angels, which will probably benefit from his weapons expertise in the future. A number of other Armed Forces' staff have also lost their security clearances and jobs because they have had close contact with motorcycle clubs with criminal reputations.

\footnotetext{
${ }^{19}$ Rigspolitiet (2013). "Rockere og bander 2012", p. 13. https://www.politi.dk/NR/rdonlyres/A80FE0FB-894 C-45D2-A408-2D9D525A1ECB/0/rockerbanderappport2012.pdf.

${ }^{20}$ This communication approach is very similar to the communicative strategy used in Operation Ceasefire in Boston; see Kennedy (2009: 2-8).

${ }^{21}$ http://edition.cnn.com/2012/08/20/us/hells-angels-lawsuit/
} 
Such contact provides grounds for believing that they could compromise sensitive information and misuse their military skills. ${ }^{22}$ Such reactions on the part of the Armed Forces will probably have as strong a deterrent effect as the threat of traditional imprisonment for criminal acts.

Social sanctions can also be applied by the labour market in general. Private individuals, local business or public agencies can avoid giving work to people and companies who are involved with outlaw motorcycle gangs. This might range from not hiring someone to not using tattoo studios controlled by the Hells Angels. This can also impact those who use the criminal services of outlaw motorcycle gangs.

One striking example of this from 1999 was a plumbing firm in the Drammen region in Norway that employed Bandidos Kapital \& Invest to collect a debt from a contractor. The two firms were in the middle of a legal dispute concerning a claim of NOK 200,000 (about USD 25,000) because the contractor argued that the plumbing firm had done a poor job. The newly established Bandidos Kapital \& Invest, run by central members of the Bandidos, bought the claim at a hefty discount. Naturally enough, when the Bandidos members turned up on their Harley Davidsons, wearing their vests and "colours" and wanted to collect the debt, they did not need to make explicit threats to convey the message that they could back up their demand with force. This was chronicled in a series of articles in the daily Aftenposten, ${ }^{23}$ which eventually resulted in Bandidos Kapital \& Invest having to close for business and the plumbing firm having to change its name because of its tarnished reputation. Even though a number of companies in the district had already contacted Bandidos to avail themselves of their services, there is reason to believe that local businesses realised that using criminal debt collectors could come with an additional price tag and decided to avoid doing so. Therefore, such incidents may have both a deterrent effect and also define norms against using the services of outlaw MC gangs.

In other words, many actors have measures at their disposal that can deter people from becoming involved with outlaw motorcycle gangs and criminal activities. The police and courts are the primary actors when it comes to applying the measures of the criminal justice system, while local authorities, business, civil society and the news media also have a number of means of implementing formal and informal social sanctions.

The target groups for such sanctions are both active and potential members of the outlaw clubs, as well as those who make use of their criminal services.

The benefits of using criminal law and other police measures for deterring the outlaw gangs are that they show that these milieux are not outside the law and constitutional society, even if they want to be. Such measures can help make members leave because the costs become too high, and those on the peripheries of the milieux pull back.

However, solely focusing on deterrence has both limitations and adverse side effects. Criminal sanctions require the presentation of legally admissible evidence and a conviction. While a large number of the members of outlaw motorcycle clubs have been convicted of serious criminal offences, it has proved difficult to impact the clubs themselves by proving they are criminal organisations. Even when key members are convicted of organised crime and the club's role has been drawn into the judgement, it

\footnotetext{
22 http://www.nrk.no/nyheter/norge/1.8410467

${ }^{23}$ For detailed references to the article series in Aftenposten, see Bjørgo (2016): 259, note 23 and 24.
} 
is still the individual members that can be punished, not the club. Clubs also try to lessen the harshness of imprisonment by providing imprisoned comrades with financial and social support. Accepting such support probably evokes an obligation to return to the gang upon release from prison. The milieu has a strong code about not informing on other members or criminal partners to the police and the courts. This norm naturally primarily applies to members of the outlaw motorcycle clubs, but there are many examples of outside witnesses being intimidated into silence. ${ }^{24}$ This can make it difficult to achieve convictions in criminal cases.

From the perspective of the rule of law and democracy, there may be problematic aspects of the informal sanctions that can be directed at outlaw motorcycle clubs. Informal sanctions initiated by public agencies or businesses can easily come to be seen as unfair discrimination and unequal treatment. For example, these informal sanctions could involve members of such clubs being refused services and benefits to which other citizens have access; or it could be that a person does not get a job or an assignment because he is a member of the Hells Angels. ${ }^{25}$ Such sanctions can also impact club members who have not themselves committed crimes, or their family members. ${ }^{26}$ Furthermore, these sorts of informal sanction may violate legal principles about people having paid their debt to society after serving a sentence for a criminal act. Moreover, outlaw motorcycle clubs make heavy use of lawyers to sue public agencies for such discrimination, and in some cases win their cases.

\section{Reducing the benefits from crime and participating in outlaw motorcycle gangs}

Participating in outlaw motorcycle gangs can provide both material benefits such as financial profit from criminal activities and intangible benefits such as an intimidating status and reputation, which in turn can be translated into more tangible benefits. The fact that some members of outlaw motorcycle clubs are heavily involved in a number of types of profit-oriented crime is well documented (see Bjørgo 2016:118, 123). Participation in profit-oriented crime goes right to the top in many of the clubs. For example, the top leaders of the Hells Angels Norway, Hells Angels Oslo and Hells Angels Tromsø have been sentenced to long prison terms for offences, including extensive drugs crimes. At the same time, clubs are careful to emphasise that when members have committed crimes, they have done so on their own without the club being involved. However, there is reason to believe that some of the money from such activities returns to the club in some form or other. If this is the case, then it could help to finance the clubhouse, which is absolutely essential for the club's existence, activities and status. It has been documented in both Sweden and Canada that the Hells Angels get $10 \%$ of the

\footnotetext{
$\overline{24}$ http://www.nrk.no/fordypning/truet-til-taushet-1.6993571

${ }^{25}$ The Norwegian National Police Directorate's 2014 handbook for the police and local authorities on preventing and combating crime originating from outlaw motorcycle clubs (Politidirektoratet 2014: 27-33) provides detailed guidance on what local authorities and business can and cannot do in relation to outlaw motorcycle clubs and their members when it comes to intervention and informal sanctions.

${ }^{26}$ An example of this was when a police raid in Bergen on a motorcycle club party affected innocent family members: http://www.bt.no/nyheter/lokalt/Kastet-MC-koner-pa-glattcelle-2864666.html\#.UUqtCBdWySo.
} 
proceeds from members' criminal activities. However, this has not been documented in Norway (Wierup and Olson 2012; Politidirektoratet 2014: 9).

In some contexts it is also obvious that the profit-oriented activities exploit the club's fear inducing aura in a very direct manner. The debt collection activities of the aforementioned Bandidos Kapital \& Invest were a clear example of this, where the Bandidos' intimidating reputation was obviously exploited to increase the willingness to pay. It is inconceivable that none of the profit from these debt collection activities ended up in the club's coffers when the business is so directly based on exploiting the club's brand.

The Hells Angels' logo (winged death skull) is actually a registered trademark, which they defend tooth and nail and also with lawyers. The Hells Angels use both legal and other means, including on occasion threats of violence, against those who try to misuse the logo. This symbol of identity and its name are the club's most important assets, and represent a major investment in both prestige and intimidation, built up through a demonstrated willingness to use violence. If there is one thing the Hells Angels fear, it is probably the withdrawal of their trademark or its losing exclusivity and protection. The Hells Angels want to control the sort of back patches and symbols other motorcycle clubs wear on their vests, and come down hard on those who try to use unauthorised patches. When some bikers tried to use the slightly satirical club name "Hells Hemmat" (a word play meaning "salutes to those back home" in Norwegian), they felt forced to change names after being subjected to pressure and threats. ${ }^{27}$

The intangible benefits are complex. When members and prospects of an outlaw motorcycle club wear their vests bearing their club patches, they are showing they belong to a club that represents subcultural traditions, but also has a long history of brutal violence. The Hells Angels in particular are highly respected in some parts of the motorcycling community for being the first and largest club. This intimidating image is also a form of criminal capital for some (Barker 2011; Wierup and Larsson 2007: 127; Korsell and Larsson 2011: 527). Operating alone in heavily criminal markets is a very risky business. Belonging to a strong club with a reputation for backing each other up and being willing to use violence if some members are having problems is a game-changer for criminals, helping them to get paid for drugs or handling other business conflicts.

Other benefits from membership may be more social in nature. In some places, members of outlaw motorcycle clubs can walk straight past queues and be admitted unhindered into nightclubs or other popular nightspots, while others have to wait their turn out in the cold. One of the most important social benefits of participating in motorcycle clubs with an outlaw image appears to be plentiful access to sexually available women and young girls. It is striking how much sex appeal these men have, in spite of their often dishevelled appearance. Some women obviously find the bad boy image attractive, ${ }^{28}$ while club parties can also provide these women with access to intoxicants of various kinds.

\footnotetext{
27 > The "Hells Hemmat" episode is discussed and commented on in the following link: http://www.bike. no/node/36546?page $=7$.

${ }^{28}$ See Kerry Krysko (2013). Kerri On: a Memoir of a Hells Angel Ex-Wife. Victoria, BC: Friesen Press. Interviewed in: http://www.torontosun.com/2014/08/03/former-hells-angel-wife-writing-new-book
} 
A Danish study (Pedersen 2014b) based on interviews with 15 former members of outlaw biker clubs and other gangs summarised the social benefits of joining these groups:

Security and community is the reason most mentioned for becoming a member but fascination about the life-style, respect from the social surroundings, and expanded possibilities at the illegal market as well as protection and support in conflicts with others are also mentioned [...] The bikers emphasize their wild parties, easy contacts with girls, joint trips and holydays, comradeship in general and the clear distribution of roles and duties as positive aspects of membership, whereas [non-biker] gang members to a larger degree mention material benefits. Both bikers and gang members experience that membership gives them muchcoveted respect and recognition from their surroundings. (Pedersen 2014b: 2-3)

The prevention mechanism in this area therefore involves making participation in criminal activities and outlaw motorcycle clubs less attractive by reducing the profits from crime as well as the social status and other intangible benefits of being a member of such clubs as the Hells Angels, Bandidos, Outlaws or Coffin Cheaters.

The measures are just as complicated as the benefits that have to be reduced. The most tangible involve seizing money and property that are the proceeds of crime and confiscating the actual criminal goods, especially drugs. In addition to seizing financial profits, there are also opportunities for reducing some of the intangible social benefits.

The prevention actors here are primarily the police and customs and excise services, as well as tax authorities, other control agencies and the courts. Customs and the police have on a number of occasions succeeded in stopping and confiscating large shipments of drugs, especially cannabis, cocaine and amphetamines, and also managed to tie these to key people in outlaw motorcycle clubs in subsequent prosecutions. Even in those cases where they have not managed to find sufficient damning evidence against the masterminds, the seizures have eliminated both their profits and investment capital, which can be substantial. In their strategy for combating organised crime, the police have increasingly focused on following the money and convicting participants of financial crimes. This is often referred to as the "Al Capone method". ${ }^{29}$ If the police, tax authorities or other public agencies discover that members of outlaw motorcycle clubs are spending more money than can be accounted for by their legal, documented incomes, property and other assets can also be seized. There are many examples of members of these motorcycle clubs abusing the welfare benefits system. In Denmark, a strikingly large percentage of outlaw gang members receive social security and other welfare benefits. ${ }^{30}$ If it can be proved that they have had undocumented incomes, this can also result in claims for repayments of welfare benefits, and possibly prosecution.

\footnotetext{
${ }^{29}$ The Chicago police never succeeded in convicting Mafia boss Al Capone for the numerous murders for which he was responsible, but he ultimately received a long sentence for tax fraud. See http://en.wikipedia. org/wiki/Al_Capone.

${ }^{30}$ A survey conducted by the Danish tax authorities' special gang unit shows that Danish Hells Angels and Bandidos members are major recipients of various forms of social security. The survey is discussed in the newspaper BT: "Hver anden rocker er på offentlig forsørgelse" (Every second biker is on public welfare) http://www.bt.dk/krimi/hver-anden-rocker-er-paa-offentlig-forsoergelse (accessed 15 February 2013).
} 
The Danish authorities have made the "Al Capone method" one of their main strategies in combating biker crime. Working closely with the police, the tax authorities manually check the taxes of both relevant people and undertakings linked to biker groups. In 2013, this resulted in 128 control cases, which resulted in adjustments to tax, VAT and duties totalling around DKK 66.7 million (USD 12.5 million). The aim of this strategy is in part to sustain the combined pressure of the police, tax authorities and social agencies on outlaw biker clubs and gangs (Rigspolitiet 2014).

What are the possibilities for reducing the intangible value and benefits of being members of outlaw motorcycle clubs and equivalent criminal gangs? A number of possible measures can be used here, with different prevention actors having different means at their disposal. As mentioned, a lot of status, prestige and fear capital are tied up in the actual symbols, especially the back patches on vests (referred to as "colours"). When a number of club members enter a nightspot wearing their vests with "full colours", they can easily establish dominance over the place and spread fear among many, as well as gaining the admiration of some. The police, local authorities and nightspots have a shared interest in avoiding this. This is why local councils and the police have in many cities encouraged local nightspots to refuse entry to people wearing outlaw biker club symbols. A number of nightspots have shown considerable willingness to impose dress codes that they have made a great effort to enforce.

One example of this from Norway was a conviction handed down by Nedre Telemark District Court on 28 February 2012. A member of the Hells Angels was convicted of threatening a doorman who had asked the person concerned to remove his Hells Angels vest or turn it inside out before coming in. The Hells Angels member turned his back to the doorman and said, among other things: "There'll be 50 men at your door tomorrow" and "One day you'll disappear if you go up against me". A tussle started, which the police got involved in when they arrived. The Hells Angels member was sentenced to 45 days in prison and had his Hells Angels vest seized. The court believed it was important to come down hard on someone who was exploiting the fear the Hells Angels name can evoke. ${ }^{31}$

This demonstrates the importance of the police and courts in backing up nightspots and doormen who try to enforce such codes, and that those who take on this challenge should be afforded the full protection of society. But, as we will discuss later, there are aspects of the practice of refusing entry to nightspots to bikers wearing back patches that are problematic, both because the legal basis for doing so may be weak and because it may conflict with more general principles concerning civil rights and protection against discrimination. Some countries, like Germany and Sweden, have a legal tradition of prohibiting the use and public display certain symbols, like the Swastika and other symbols associated with Nazism, and might possibly extend this to symbols associated with outlaw MC clubs. Such a general prohibition of symbols would be considered unconstitutional in other countries, e.g. the USA.

As mentioned, one of the most important social benefits of participating in outlaw motorcycle gangs is that the milieu and the rough men appear to attract a striking number of women. As one woman who was herself the girlfriend of a Hells Angels member said in her blog:

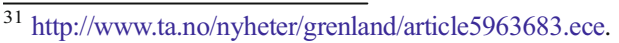


"This thing about women liking Hells Angels is not rubbish; when a man puts on his vest and goes into town he is surrounded by everything from leggy blondes who snuggle up to him to mature women who give him long looks. What is it with these motorcycle guys and women...?"32

This dangerous but attractive image and the sexual benefits it can bestow make being a member of the Hells Angels or Bandidos attractive to some young men. So, can anything be done to get these women to stay away from this criminal milieu? Some women are probably attracted by the physical power the outlaw bikers display. One option could be for the police and other actors to deprive them of this power and instead show their impotence. Another possibility is reducing access to drugs. The police can also raise the levels of discomfort and risk that are associated with getting involved with gang members, including by regularly checking and registering who is part of the criminal milieu. Women who take part in parties at outlaw motorcycle clubs should be told by the police that they could be registered and thus risk negative consequences later on if they socialise with these criminal milieux. A District Sheriff from a Norwegian municipality where a Hells Angels club is located was asked by a journalist:

"Does [the local] Hells Angels [...] attract young women from [this area]?"

"Yes. We saw this, among other things, when we stopped all those going to the ten year anniversary [of the local Hells Angels club] last year. Everyone on their way into the party was photographed, among other things. There were some women aged as young as 18-20 who didn't really know what they were getting involved in. Some were surprised that the police were there. Many didn't understand the seriousness of the situation," says [District Sheriff] Krogstad. ${ }^{33}$

The consequences could, for example, become clear should some of these women subsequently want a job in which they need security clearance. The reason for this is that they could end up in situations later on where they risk being blackmailed, for example because of compromising pictures involving sex or drugs. Besides, women who seek to join this milieu need to be informed of the very real risk they run of ending up being treated as the "club's property". Women who have participated in the Hells Angels have described how degradingly women can be treated and abused. Women who are invited to parties in the clubhouse are treated as consumables and often referred to as "vest whores" (Wierup and Olson 2012). ${ }^{34}$ Explaining such experiences may provide some opportunities to make the milieu less attractive.

The target groups for these measures for reducing the tangible and intangible benefits are primarily members of the outlaw motorcycle clubs, but also include their wider social environment and those who look up to them.

\footnotetext{
${ }^{32}$ From the Kvinneguiden web forum: http://forum.kvinneguiden.no/index.php?showtopic=708481 (accessed 15 February 2013).

${ }^{33}$ See http://www.h-a.no/Nyheter/Nyheter/tabid/72/Default.aspx?articleView=true \&ModuleId=113899 (accessed 15 February 2013).

${ }^{34}$ For more on women's ranking order in the Hells Angels, see http://www.expressen.se/kvp/kvinnorna-ar-endel-i-freden-mellan-gangen/ (accessed 18 May 2014). For the story of a former Hells Angels wife: http:/www. torontosun.com/2014/08/03/former-hells-angel-wife-writing-new-book (accessed 04.11.2014).
} 
The benefits of these measures are first and foremost that they can help to make seeking to establish ties with outlaw motorcycle clubs less attractive. This may help reduce access to potential new prospect recruits (and thus access to criminal errand boys) when they see that crime does not pay. It may also help stem the inflow of women to the milieu, which can prevent the women being abused and having other negative experiences, and also reduce the milieu's attractiveness to male recruits.

Some of the most relevant measures also have limitations and unintended side effects. Several of the most effective measures require a legal basis that may not necessarily exist. Significant legal restrictions (both in many national legislations and the European Convention on Human Rights) apply with respect to the extent to which authorities can encourage businesses to refuse to serve people in nightspots who are wearing motorcycle clothes with club patches. Imposing a ban and refusing entry to people wearing clothing that signals membership of a specific group is problematic. Such a ban must also apply to everyone else who wears clothes with a clear identifying symbol, for example those of ordinary motorcycle clubs or football club fans.

However, the involvement of public agencies in private matters, such as women being attracted to "bad boys" from the outlaw milieu, may also be considered highly problematic. Some of the measures associated with reducing the intangible benefits of club membership may, with some justification, be perceived as discriminatory and as unfair harassment. The Hells Angels and similar clubs have established their own organisations in a number of countries that are intended to defend the civil rights of outlaw club members, including by helping to fund legal assistance from top lawyers. PayBack is an umbrella organisation for bikers' rights in Norway, Denmark and Sweden. ${ }^{35}$

\section{Disrupting planned violent and criminal acts}

The prevention mechanism in the disruption strategy involves preventing criminal acts by detecting and stopping planned acts before or during their execution. One of the main purposes of disruption is to prevent harm caused by criminal acts. Disruption can take place both before and after an act has crossed the line and becomes punishable in a legal sense.

A number of measures are available, depending on the stage of the disruption process. Surveillance, bugging, infiltration, using informants and other covert methods may be vital police techniques for detecting that a criminal act is being planned and prepared. If the plans appear to be genuine and will soon lead to a criminal act, the police will have to assess when to step in and the risk that waiting involves. The target groups are active criminal gang members and their supporters (indicated prevention), as well as people that are at risk of being recruited into criminal activities (selective prevention).

One example of late disruption through advance intelligence is a planned bank robbery in Oslo in $2004 .{ }^{36}$ The police had good intelligence information that showed

\footnotetext{
35 Payback Norway has its own Facebook page: https://www.facebook.com/pages/PayBackNorge/135351236538583. The leader was interviewed in the Norwegian National Police Directorate's magazine. Norsk Politi (no. 2, 2012, pp. 28-29).

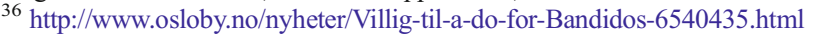


that a central member of the Bandidos, a former neo-Nazi and a third person, who was an experienced armed robber, would carry out an armed robbery at a specific time. The police were able to prepare a surprise ambush, which involved deploying the Police Emergency Response Unit (SWAT team) in advance, enabling them to arrest the armed robbers before they got anywhere near the money. One of the robbers tried to flee by jumping into a canal, but quickly had to give himself up. All three were sentenced to long prison terms.

There is also an example of late disruption without advance intelligence. During the "Great Nordic Biker War" (1995-1997) the murder (or attempted murder) of the leader of the Outlaws Norway, Tore Henki Holm Hansen, was probably disrupted. By chance, security guards discovered two Hells Angels members sitting in a car parked outside the home of the leader of the Outlaws. The police were alerted, and when they searched the car they found weapons and other items that suggested an assassination was planned. ${ }^{37}$

Another form of disruption is when Customs and Excise and/or the police manage to stop and seize a shipment of drugs before it reaches the market. In such cases, a large number of user doses will then be prevented from reaching drug abusers and doing physical harm. When the police manage to stop shipments of drugs like this, some of those involved will, as a rule, also be arrested and punished for the criminal acts they have committed. However, opportunities often present themselves for disruption at even earlier stages, where the goal is to prevent the offences occurring so that no prosecution is necessary.

A hypothetical example is as follows. If the police in one of the Scandinavian countries, through their intelligence activities, were to discover that local Hells Angels members have started to hang out with a lorry driver who drives loads to and from Central Europe, there would be reason to suspect that they wanted to use him as a courier to smuggle drugs. Traditionally, the police would wait to see if the situation develops further so they can start surveillance and other activities that will enable them to arrest the lorry driver once he crosses the border with his cargo of drugs. The hope of course is to catch (and punish) the masterminds behind the smuggling as well, but this has often proved more difficult than catching the courier. An alternative strategy that the police are increasingly using is to disrupt the actual criminal act through early intervention and dialogue or warnings. In such a (hypothetical) case, the police would contact the lorry driver directly and say something along the lines of:

"We know that NN in the Hells Angels is trying to establish a relationship with you and we know what he is after, he wants to persuade you to carry drugs from Central Europe. Now, you have two choices: you can continue on this path and if you do we guarantee that you will be caught. That would mean you will not be playing football with your three-year-old son before he is a teenager. You will have to watch him grow up from a prison cell. Or you can turn back now, and break your ties with your Hells Angels contact. Then you can live a good life with your family and be an important person for your son. It's your choice."

\footnotetext{
${ }^{37}$ However, the two were acquitted of attempted murder by the court, partly because their explanation of why they were heavily armed outside the leader of the Outlaws' home could not be definitively refuted.
} 
Many of the people the police contact and speak to directly like this will probably choose the latter alternative and refrain from participating further in such a criminal project - especially when they realise how likely it is that they will be caught and when the consequences this will have are explained to them in such a clear fashion (cf. Kennedy 2009: 5-6). This type of early intervention has a number of major benefits: it is cheap for society because the taxpayers' money does not have to be spent keeping the lorry driver (and possibly fellow conspirators) in prison for many years. Keeping the person out of prison also saves him and his family from suffering, because he can continue his life as before. One drawback is that the Hells Angels mastermind will probably try to recruit new couriers. On the other hand, he would probably have done this anyway had the first courier ended up in prison and he had got away. With this early intervention approach the police also lose the chance to punish and incapacitate the mastermind behind the scheme. However, the police also have the option of having a similar preventive dialogue, including a strong warning, with the criminal masterminds: "Don't try it! Because we'll catch you!" This will probably work on some, but not everyone. Another drawback of this method is that the police's suspicions may be wrong and the lorry driver might have no intention of being persuaded to carry drugs. Being contacted by the police and accused of being in the process of becoming a participant in criminal activities could in these circumstances be regarded as offensive. If the police also contact family members in order to get them to put moral pressure on the person concerned, and the suspicions prove groundless, this could be even more problematic. ${ }^{38}$

Another example is when the police issue warnings in order to try and stop menacing debt collection. People who have been visited by threatening Bandidos or Hells Angels members in connection with a disputed payment (e.g. in connection with the purchase of a used car) have contacted the police to get protection. The police have then had a serious talk with the hired guns concerned, and made it clear that they are not taking a position on the actual question of debt, but that the police have now noted that the Bandidos/Hells Angels member has attempted to collect money with threats of violence. If the person concerned is subjected to anything along these lines, then the police will come down hard. This has usually resulted in the person being threatened by debt collectors being left in peace. ${ }^{39}$

Disruption strategies generally have many more benefits and advantages than more reactive strategies. Firstly, disruption can reduce both the suffering of potential victims and the (direct and indirect) costs of imprisonment. This strategy can also be a great help in managing the police's chronic lack of capacity. One recurring dilemma for them is that they learn about far more crimes than they have the capacity to investigate, prosecute and secure convictions for. In practice, this means that a large number of cases are dropped owing to capacity constraints because they are too resourcedemanding to investigate. In some of these cases it would have been beneficial had the police stepped in with a strong warning at an early stage, which does not need a lot of resources and requires little evidence and documentation. Such interventions

\footnotetext{
$\overline{\left.{ }^{38} \text { However, this would be permissible under Norwegian law (Politiregisterlovens } § 27\right): ~ " C o n f i d e n t i a l i t y ~ d o e s ~}$ not hinder the police from passing on information [...] to private citizens if this is necessary to prevent a crime and other solutions are considered insufficient."

${ }^{39}$ Several well-informed police officers describe such preventive conversations as a method often used by the Oslo police in relation to hired guns from motorcycle gangs.
} 
probably have no effect at all in most cases, but in some cases they may make someone abort a criminal act or refrain in future. The effects of this low-level intervention through warnings are probably more beneficial than the alternative - the police simply dropping a case without doing anything, which can easily be perceived as the police not caring about such criminal acts.

In some cases, early intervention with a warning from the police may also help to break potential spirals of violence in connection with conflicts between motorcycle gangs and similar groups.

The drawbacks and negative side effects may be, as mentioned earlier, that innocent people come under suspicion and are stigmatised, and there can be problems associated with the duty of confidentiality. Besides this, disrupting "small fry" can result in the masterminds not being caught, thereby giving them an opportunity to start new criminal projects.

\section{Incapacitation - denying outlaw motorcycle gangs the ability to carry out criminal activities}

As far as incapacitation is concerned, the prevention mechanism involves depriving criminals of the ability or capacity to commit criminal acts or, more generally, run their criminal activities. The target group here is criminal actors in outlaw motorcycle clubs and their support groups and partners (indicated prevention). The police and courts system are the principal actors, but other public agencies and control bodies can also play important secondary roles.

The measures can be targeted at specific individuals or specific kinds of criminal acts, but can also be targeted in a relatively general manner at the milieu and organisation, or seek to limit the milieu's access to weapons and other resources that can be used in criminal activities.

The most obvious form of neutralisation is convicting people who have committed criminal acts and putting them in prison for a long time. This limits their opportunities to participate in criminal activities, at least to some degree. A large number of leaders, members and associates of the Hells Angels, Bandidos, Outlaws and the other outlaw motorcycle clubs have been successfully sentenced to long prison terms for various kinds of criminal activity such as drugs offences, violence, robbery and other crimes. If a number of the key people in an outlaw motorcycle club are locked up for a long time, this can also have consequences for the club's ability to function. During times of conflict with other clubs or gangs it may be necessary to ensure the clubhouse is manned at all times, $24 \mathrm{~h}$ a day, seven days a week. This can be quite a heavy burden if the club consists of fewer than ten members and some of them end up in prison. If the club cannot mobilise sufficient numbers to keep running, the club risks having to close, being "frozen" or being thrown out of the parent organisation.

Incapacitating key leaders through imprisonment may also drastically reduce activity in the milieu, and sometimes causes groups to disband completely. One example of this involves AK81 in Trondheim, a "street crew" which was established by the then president of the Hells Angels in Trondheim (and Norway) to perform services for the club. He played a key role in recruiting these violent and criminal young people, and he gave them specific jobs to do and recognition for what they did. When the Hells Angels 
president was detained and subsequently convicted in a major drugs case it weakened the Hells Angels' grip on these young men and AK81 ended up disbanding, arguably because the key Hells Angels leader was put out of play.

The police regularly check and search people with ties to outlaw motorcycle clubs and their vehicles and clubhouses. It is not rare for the police to discover illegal firearms or explosives that can thus be seized. According to the Danish National Police's status report for 2013, the police seized at least 87 weapons that year that definitely belonged to people in the "biker or gang milieu". Similar weapons seizures also occur in Norway:

"In January 2011, the police raided the Hells Angels' clubhouse [...] in Oslo and found 13 handguns hidden in walls and ceilings. The clubhouse was basically taken apart during the search. In January 2012, the police raided the Bandidos. A weapon loaded with live rounds was found." (Norsk Politi no. 2, 2012, p. 24)

Taking such weapons out of circulation reduces the gangs' capacity for violence. Reducing the arms race between criminal gangs can also reduce their mutual fear of each other, which can in itself help to break the vicious circles that lead to arms races in gang milieux (Bjørgo et al. 2005: 71-72, 226).

Another form of incapacitation involves revoking driving licences or seizing vehicles such as cars and, not least, motorcycles. Since the consumption of various types of intoxicants in outlaw motorcycle clubs is extensive and members have little respect for society's laws, there is reason to believe that people in these milieux drive under the influence of drink or drugs quite frequently. If the police carry out checks at relevant places and times (e.g. in connection with parties in clubhouses) with a view to catching people who are driving under the influence, the chances are high that some will be caught and lose their licences. If the vehicles are used in criminal activities, if for example a hired gun rides his Harley Davidson motorcycle up to the front of someone's home before threatening them for money, then there is also a chance that the court will seize the motorcycle. However, at least in Norway, this is an option that the prosecution authorities and courts have made little use of because it requires them to prove a direct connection between using the vehicle and carrying out the criminal act. But there are many examples where vehicles that have been used repeatedly for smuggling have been seized. ${ }^{40}$ As mentioned earlier, a member of the Hells Angels was sentenced to 45 days in prison and had his vest with his Hells Angels back patches seized after making threats when he was refused entry to a nightspot that prohibited the wearing of "colours". It was precisely because he referred to the back patches on his vest to reinforce his threats that the court found there were grounds for seizing his vest. His appeal was later rejected by the appeal court. Since the vest with its back patches was an important part of the threat capacity, this can be regarded as a form of incapacitation. Having your vest and "colours" seized also constitutes an important, symbolic loss of status internally in the clubs. Vests bearing Hells Angels back patches are the property of the club. It is not a given that the person concerned will be given new patches by the club, especially if he is deemed to have misused the club's colours. In these circumstances there is a good chance of being thrown out in "bad standing".

\footnotetext{
$\overline{40}$ http://www.aftenposten.no/nyheter/Tre-polakker-domt-for-smugling-smuglerbilene-blir-inndratt7142057.html (accessed 11 March 2013).
} 
Preventing an outlaw motorcycle club establishing itself in a community or in a particular property can help to reduce the club's capacity to run its activities. This is discussed in more detail in the next section.

One benefit of the incapacitation strategy is that imprisoning key people/leaders can be an effective way of paralysing a network, especially if several key people are put out of business simultaneously. This is particularly true of people who bring together a number of essential actors and functions in a network, and who cannot easily be replaced (Sageman 2004: 140-141). While repressive measures are implemented against such central actors, more positive measures can be offered to people who are on the periphery of a network, possibly in combination with sanctions which make continued participation uncomfortable.

Good policing responses need to [...] rely on methods that sift the criminally active members from the rest of the club. Selective removal of offenders through quality police work will strengthen the traditionalist factions and potentially reduce the serious criminal activity of clubs and chapters (Lauchs et al. 2015: 37).

One of the limitations of incapacitation as a strategy is that individuals can often easily be replaced in a criminal gang, especially when the milieux are of a certain size and many people have the same skills and connections. Removing one actor from a criminal marketplace often just makes way for another. If, for example, key people in a network of drug suppliers originating in an outlaw motorcycle club are imprisoned, this may weaken the club so much that other criminal groupings can come in and take control of the local market. Struggles for such markets can also result in violent conflicts. Another limitation of the incapacitation strategy is that convicted criminals often continue to "pull the strings" in criminal projects and milieux even when they are behind bars. Few people are subjected to such strict prison regimes that they are cut off from all contact with their old criminal partners. Imprisonment is often used to make contacts and plan and organise new criminal projects. Members of outlaw motorcycle clubs usually have a high status in prison, and making "friends" with them is attractive for other prisoners. On top of this, incapacitation through long prison sentences for many gang members is generally an expensive crime-fighting strategy for society.

\section{Reducing criminal opportunities and protecting threatened people}

The prevention mechanism involves eliminating or reducing motorcycle gangs' opportunities to carry out criminal activities, and identifying and eliminating opportunities to carry out specific types of criminal acts. This may involve making detection more likely, making the carrying out of criminal acts more demanding, or protecting potential victims so they cannot be coerced or threatened. These mechanisms form part of the socalled situational prevention strategy (see Bjørgo 2016: 26-28), which aims at reducing opportunities for crime by changing the situations in which crimes occur. Since outlaw motorcycle clubs place great store on territorial dominance as part of their subcultural identity, preventing them establishing a presence in a local community in a way that allows them to achieve this sort of dominance can also be an important strategic goal. Another goal may be to prevent them gaining control over local or regional criminal 
markets, especially when it comes to selling cannabis and (meth)amphetamine, and (in some countries) prostitution.

There are many actors in this prevention strategy that can play important roles because they have a range of different measures at their disposal. One of these of course is the police, but they also include local authorities, place owners, security guards, doormen, businesses, legislators and control agencies such as tax authorities and labour and welfare agencies. The general public can also help in various ways.

The target groups these measures are aimed at are primarily active or potential offenders, with a view to getting them to refrain from criminal acts, or limiting their room for action. However, some of the measures are also intended to protect potential victims from threats and coercion.

The measures within this strategy can be legal as well as political and administrative, or be based on various kinds of formal or informal control. A local community may want to prevent an outlaw motorcycle club establishing a local clubhouse. This may be motivated by the crime that is often associated with these clubs (e.g. violence or selling drugs), the potential for violent conflict between rival clubs and gangs, and the fear these groups engender in their neighbourhoods. Some of a local authority's most important measures are building and licensing regulations, which provide a basis for regulating how individual properties may or may not be used.

Members of the Hells Angels, Bandidos and other outlaw motorcycle clubs are often heavily involved in both legal and illegal businesses, and the dividing line between these can be quite fluid. It is precisely the opportunities afforded by being able to switch between the legal and illegal spheres that provide opportunities for extra profit. Profits from criminal activities can be invested in, and laundered through, legal firms. At the same time, there are many examples of where apparently legitimate firms have used direct or veiled threats, committed VAT fraud and used other illegal methods to obtain unfair advantages when competing with "normal" firms.

The Hells Angels in Finland are, for example, involved in more than 80 firms with a total turnover of more than EUR 60 million. ${ }^{41}$ The Hells Angels in Norway controlled around 60 companies in 2010. ${ }^{42}$ In Sweden, the Bandidos have run extensive extortion rackets by offering restaurants and bars "protection" from other criminal gangs. ${ }^{43}$ As mentioned before, the Bandidos in Norway established a debt collection company, Bandidos Kapital \& Invest (which was subsequently closed down). Route 81 is the Hells Angels' own confectionery company, which raises money for the Defence Fund, a fund that supports the families of imprisoned Hells Angels members. ${ }^{44}$ The brand name of the House of Pain tattoo chain is owned by the Hells Angels, and the local branches are often run by Hells Angels members as franchise holders. Many of the branch managers have been prosecuted for financial irregularities. The leader of the Hells Angels in Norway, Leif Ivar Kristiansen, was behind the House of Pain and owns three tattoo and piercing studios, including Tattoo World in Trondheim. In the extensive court case against Kristiansen in the spring of 2011 it came out that he had directly threatened the female owner of a competing piercing studio in Trondheim in an attempt

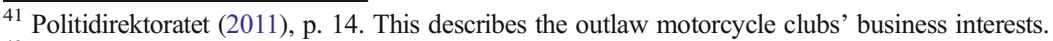

42 According to the Norwegian Broadcasting Corporation's "Brennpunkt" programme. http://www.nrk. no/programmer/tv/brennpunkt/broderskapet/1.7015805 (accessed 10 September 2014).

${ }^{43}$ Wierup and Larsson (2007), also see http://www.thelocal.se/9046/20071108/ (accessed 12 March 2013).

${ }^{44}$ http://tux1.aftenposten.no/nyheter/iriks/d200838.htm (accessed 13 March 2013)
} 
to get her to close her business. ${ }^{45}$ This is a clear example of illegal methods being used to support what is, in principle, a legal business. It is important that the police and other agencies robustly support businesses that are under pressure from these clubs, so that they are unable to establish dominance, gain privileges through threats or force other competing businesses to stop trading.

A key situational prevention mechanism is eliminating opportunities for criminal profit. With respect to strong-armed debt collection, up until an amendment to the Norwegian Debt Collection Act was passed in 2000, loopholes in the law made it possible for almost anyone to buy up claims (often for well below their face value) and collect on them with a substantial profit. This is why firms such as Bandidos Kapital \& Invest were established.

The fact that up until 2000 it was actually legal in Norway for anybody at all to buy outstanding claims at a discount, and collect on them, gave the Bandidos and Hells Angels an opportunity they knew how to exploit. Their reputation gave them a competitive advantage, not least when it came to collecting on claims that other debt collection agencies would have given up on. It was precisely for this reason that the Storting (the Norwegian parliament) asked the Norwegian Banking Law Commission to produce an additional report (Report No. 5 NOU 1999:31) on "The purchase and collection of debts, etc."

... Based on this, the Ministry [of Justice] proposes several changes to the [Norwegian] Debt Collection Act to counter unfortunate aspects of debt collection and thus improve the debtor's situation. Firstly, the Ministry proposes introducing a licensing requirement for undertakings that purchase and collect overdue money claims. Furthermore, the Ministry proposes introducing a debt collection licence for undertakings instead of personal debt collection licences in relation to the right to operate a debt collection business. [...] On their own and combined these proposals will follow up the Storting's desire to prevent heavyhanded collection methods in debt situations. (Norwegian Debt Collection Act Proposition to the Odelsting no. 26 (2000-2001) (amendment act), p. 6.)

This amendment resulted in outlaw motorcycle clubs no longer having an opportunity to collect "legal debt". On the other hand, there is little reason to doubt that they would still collect outstanding claims in the illegal, criminal part of the economy. Nonetheless, the important thing about the amendment is that it reduces the room for manoeuvre in which criminal actors can operate in the grey area between legal and illegal business.

There are also some possible limitations and adverse side effects from following this strategy to its conclusion. If a local authority takes advantage of all the opportunities it has to, for example, prevent a motorcycle club establishing a clubhouse in its community, this may conflict with fundamental human rights such as the right to organise and the right of free assembly, as well as equal treatment principles. Some of the measures discussed above may be perceived as discriminatory against members of outlaw motorcycle clubs, especially those who are not directly involved in criminal activities. Some of the police's interventions aimed at unsettling the milieu may be characterised

\footnotetext{
45 The owner of the competing piercing studio witnessed in court and told how Kristiansen had threatened her. http:/www.nrk.no/nyheter/distrikt/nrk_trondelag/1.7581501 (accessed 12 March 2013).
} 
as harassment, not least when they impact members who are not involved in criminal activities. The fact that participants in a club that is associated with crime choose to start legal businesses might conceivably be a serious attempt to lead a law-abiding life. If unreasonable obstacles are put in the path of such attempts to earn an honest living, this might lead them down the path to the illegal economy.

\section{Reducing the harmful effects of outlaw motorcycle gangs' activities}

Violent conflicts between the various outlaw motorcycle clubs or with other gangs have resulted in serious harm, not just to each other but also to local communities, as was described in the introduction to this article. In addition to this comes the harm that occurs from the profit-oriented criminal activities that club members are behind, especially the distribution of drugs. These clubs can also engender a general sense of fear and insecurity.

In this context, harm reduction as a crime prevention mechanism involves reducing the negative consequences of the outlaw motorcycle gangs' presence, activities and criminal acts, and in particular managing conflicts in a way that prevents serious violent consequences for local communities. Harm reduction can be considered a pragmatic strategy for dealing with crime and criminal milieux. It can also be understood as reality-oriented acceptance of the fact that outlaw motorcycle clubs exist and will continue to exist in the future. Rather than dedicating all resources to combating the existence of these motorcycle clubs, the police and other authorities may instead try to restrict their room for action such that they cause the least possible harm through crime and violence. Harm reduction has been a more well-known strategy within the area of drugs, where it includes measures such as drug injection rooms, methadone assisted treatment programmes and various forms of drug use decriminalisation. In its more radical form this pragmatic approach to crime is controversial because it breaks with the traditional repressive methods of fighting crime and "zero tolerance". However, a harm reduction strategy can actually be reconciled with the police operating a zero tolerance policy towards criminal acts while tolerating the current and continued existence of outlaw motorcycle clubs and maintaining a dialogue with them to control their behaviour. Meanwhile, there are also other measures and forms of harm reduction that are far less controversial and which involve crisis management and victim support. These are discussed elsewhere (Bjørgo 2016: 28-29, 63-67, 106-111, 183-185, 223-227).

Here we will look at what can be described as a harm reduction and control strategy for outlaw motorcycle gangs as it has been practised in the Oslo Police District. ${ }^{46}$ The key measure in this strategy is dialogue. It is no secret that this method has been controversial within the police force. Most agree that dialogue is a useful tool, including when it comes to criminal groups, or more specifically when communication is used as a tactical approach. The disagreement concerns the extent to which dialogue should be

\footnotetext{
${ }^{46}$ This description is largely based on a public report published by Oslo Police District and written by Stubberud and Jensen (2011). Everything starts and ends with a handshake - Dialogue with gang structures, experiences, results and advice. https://www.politi.no/vedlegg/lokale_vedlegg/oslo/Vedlegg_1548.pdf (accessed 13 March 2012) and the article "Strenge spilleregler" (Strict ground rules) in Norsk Politi no. 2, 2012. I have also spoken to some of the police staff who have been involved in the dialogue work.
} 
an overarching strategy or just one of many measures, and the degree of symmetry in the dialogue.

Since 2001, the Oslo police force's experiences of talking to political activist milieux have been very positive when it comes to controlling demonstrations, thus ensuring that both freedom of speech and public order are protected. This has made the taking on of the role of demonstration facilitator by the police relatively unproblematic (Bjørgo 2014). Similarly, dialogue has also been used in relation to the outlaw motorcycle clubs that are established in the city, the Hells Angels and Bandidos. The strategy of the Oslo police force in relation to these two clubs has largely involved controlling their activities by restricting their room for action. This has been done by talking to leading people in the milieux, and the police making it quite clear which rules apply. If instructions are not complied with, the police will use force, and not following the agreed ground rules can have dramatic consequences for the motorcycle clubs. ${ }^{47}$ However, this dialogue strategy became controversial in the police force because some felt that the communication with the Hells Angels/Bandidos had moved too far in the direction of a symmetrical dialogue between two equal parties, and that this had in some contexts helped to facilitate the clubs' activities and events. ${ }^{48}$

The main benefits of this dialogue strategy are that it appears to have clearly reduced violent conflicts between the outlaw motorcycle gangs in Oslo. It helped to prevent the establishment of other outlaw gangs in the capital, and neither the Bandidos nor the Hells Angels have established support groups that recruit young people for violent jobs or other crime. The Hells Angels and Bandidos have largely accepted that they cannot wear their vests with back patches in some contexts in public, including in nightspots in Oslo. The head of the organised crime section in Oslo Police District, Einar Aas, stated in 2013 that these motorcycle gangs "behave in a manner that is tolerable". The dialogue strategy reduces the level of conflict between the motorcycle gangs and the police, and saves a lot of staff resources because there is usually no need to assign 20 officers when most things can be handled by two. Arrests of individual Hells Angels and Bandidos members can normally be carried out by a couple of officers without resulting in serious conflict.

There are some limitations and problematic aspects of this dialogue strategy as it has been practised in Oslo, which has helped make this method, or more specifically dialogue as a primary strategy, controversial within the police force. One overarching question in this context is whether dialogue involves negotiating or telling the gangs how things should be. It could be argued that the dialogue has given the Hells Angels (and possibly the other clubs) too much power in that they can threaten to break off the dialogue if someone in the police does or says something they do not like. Dialogue as a primary strategy requires a consistent line on the part of the police locally, but also to some extent nationally. If some police patrols in the capital operate a confrontational policy with ongoing agitation bordering on harassment of Hells Angels or Bandidos

\footnotetext{
${ }^{47}$ The Oslo police force's dialogue strategy is described in the magazine Norsk Politi no. 2, 2012. https://www.politi.no/vedlegg/lokale_vedlegg/politidirektoratet/Vedlegg_1853.pdf (accessed 20 May 2014). Also see Stubberud and Jensen (201̄).

${ }^{48}$ A controversial incident occurred in April 2014 when the Hells Angels were allowed to arrange a funeral in Oslo Cathedral for a member who had died. The Hells Angels took it upon themselves to direct the traffic at a number of junctions when many hundreds of members rode in a motorcycle cortège through Oslo. http://www. osloby.no/nyheter/Hells-Angels-dirigerte-Oslo-trafikken-7180264.html
} 
members, this will undermine the trust on which the dialogue strategy is based, and it will be broken off or disrupted.

The police's dialogue with the motorcycle gangs in Oslo has also been heavily dependent on the individuals involved. Most of the dialogue has involved one specific officer who has managed to establish a relationship of trust with the key people in the gangs. Such a dialogue would be put at risk were this police officer to leave or his duties change, which is what happened in Oslo in $2013 .{ }^{49}$ In the wake of this there was a marked change in the Oslo police force's policy towards the Hells Angels in the autumn of that year, when the police, in a far more confrontational manner, tried to seize the Hells Angels' clubhouse owing to the confiscation of a large number of illegal weapons made in the clubhouse in January 2011. The police's seizure attempts were unsuccessful in court, but the motorcycle club had to pay a fine of NOK 750,000 for violating firearms law. ${ }^{50}$

The tug of war between different strategies is based on the Oslo police force's dialogue strategy being viewed by many in the police as conflicting with the more uncompromising form of fighting crime that the Norwegian National Criminal Investigation Service (NCIS, or KRIPOS), most police districts and also many in the Oslo police force want to conduct. The police in Denmark have followed a strict confrontational line towards motorcycle gangs, which was expressed as follows by Assistant Chief Constable Kim Kliver, then head of the Danish national intelligence centre (NEC): "The dialogue with these criminal milieux should take place in front of a judge in a courtroom!" ${ }^{51}$ In a Norwegian context, taking a position that rejects all dialogue with outlaw biker gangs appears rather counter-productive as the police dialogue with the outlaw biker clubs and other gangs in Oslo has clearly served to reduce armed conflicts between the gangs, which may also harm the surrounding society. ${ }^{52}$

Because the pragmatic strategy of harm reduction, control and dialogue with the motorcycle gangs appears to have achieved some positive results in Oslo with respect to limiting crime, public order problems, violent conflicts and recruitment to the milieux. However, it is not a given that other (and smaller) police districts will be capable of implementing this strategy with the same results. One of the reasons for this is that they are less able to back up their demands with force. It is also claimed that even if the policy of dialogue with the outlaw motorcycle clubs has resulted in their constituting less of a crime problem in Oslo, members of the Oslo clubs are still key players in criminal activities in other parts of the country. In December 2013, one of the most central members of Hells Angels Oslo was sentenced to nine years in prison under the Mafia paragraph and for serious drugs offences in a major case in the far north of Norway. ${ }^{53}$

\footnotetext{
${ }^{49}$ The police officer who had played a key role in the dialogue with the motorcycle gangs in Oslo was arrested and detained by the police on 24 February 2014 on suspicion of corruption and involvement in drug crimes following accusations made by a criminal with whom he had had a long-standing personal relationship. At the time of revising this article (April 2017) he was on trial. Whether evidence is sufficient for conviction is still an open question.

${ }^{50}$ Oslo City Court - TOSLO-2013-176,606 (obtained from Lovdata.no).

${ }^{51}$ Also see the Norwegian National Crime Prevention Council 2014: 48. The statement by the head of the Danish NEC, Kim Kliver, was made at a seminar in Copenhagen, 23-24 March 2011, for Norwegian mayors, councilors, and police officers.

52 This view was expressed in the judgement by Oslo City Court - TOSLO-2013-176,606.

${ }^{53} \mathrm{http}$ ://www.nrk.no/nordnytt/knusende-kjennelse-over-ha-folk-1.11358559 (accessed 27.01.2016).
} 


\section{Exit: Getting gang members to disengage and outlaw MC gangs to dissolve}

In principle, many criminal gangs and extremist groups do not accept any members leaving, and such defectors may be subjected to threats and reprisals, in part because they know the group's criminal secrets. On the other hand, most outlaw motorcycle clubs have formal procedures for ending participation in the group: members can leave in "good standing" or in "bad standing". Leaving in "good standing" means you have to hand over your vest and other symbols, and that you lose all of your rights as a club member. However, you may still be considered a friend of the club, and some social ties with your former comrades may continue; such former members may be invited to parties and other social events. Unless there is a definitive break, though, the police and public agencies may have a more or less justifiable suspicion that these people are also expected to perform "favours" for the club because they are friends, which may have consequences for security clearances and job offers, for example. Thus, if former members are not thought to have broken sufficiently from the criminal milieu to which they formerly belonged they may still experience negative consequences. Traditionally, there appear to be a few acceptable ways out of a club: having family obligations with respect to girlfriends and children, getting a job or "seeing the light" after a fundamentally life-changing event, for example a religious conversion. ${ }^{54}$ Some also experience problems because they have a serious criminal record that makes it difficult to get a job, or perhaps also sentences that they have to serve. There are also those who leave motorcycle clubs but move on to other criminal activities.

Members who have broken the club's written and unwritten rules may be thrown out in "bad standing". They may experience various degrees of reprisals, from icy ostracism to extreme violence. There are examples of excluded members being brutally killed by their former comrades or having their club tattoos removed with angle grinders. ${ }^{55}$ Members who are thrown out like this and are subjected to reprisals will in some cases want to "get their own back" against the club by speaking out or taking the witness stand. Some have come forward in the media and revealed what the Hells Angels and Bandidos are really about, ${ }^{56}$ or have described their experiences in books (Wierup and Olson 2012; Matter and Omodt 2014).

A Danish study (Klement and Kyvsgaard 2014) documents that Danish biker clubs and their support groups have a surprisingly high turnover of members. The study was based on who was registered by the police as members of these groups in June 2009, October 2012 and October 2013. An analysis was made of who joined and who left (i.e. were no longer registered as active) at these three points in time. From June 2009 to

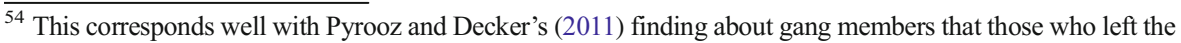
gang due to pull factors from outside the gang, i.e. new family obligations, job opportunities, education and similar, could all leave without hostile reactions from the gang, whereas those who left because of push factors, such as becoming fed up with gang life and violence, to a much larger extent experienced violent reprisals from their former gang comrades.

55 "Torterade man med slipmaskin: Hells Angels president Bengt Olsson, 45, berättar om varför han hoppade av. gänget" (Tortured man with angle grinder: Hells Angels president Bengt Olsson, 45, describes why he left the gang). Aftonbladet 28 February 2009. http://www.aftonbladet.se/nyheter/article11676479.ab (accessed 20 March 2013).

${ }^{56}$ The Norwegian Broadcasting Corporation's "Brennpunkt" programme "Engler uten grenser" (Angels without limits), 2 March 2010. The programme is no longer available online because of copyright issues and the sensitivity of the material.
} 
October 2013, 45\% were newcomers, $24 \%$ were still members and $31 \%$ had ended their participation by October $2013(N=1662)$. As might be expected, member turnover was higher in the support groups AK81 (Hells Angels) and Mexican Teamwork (Bandidos), whose members are also generally younger. However, a significant proportion was no longer registered as active members of the Hells Angels and Bandidos at the third point in time, and had therefore probably left. The vast majority of these had probably left of their own volition, without the support of an exit programme. ${ }^{57}$ Only a small number, 18 people, had left the milieu before subsequently resuming their participation (Klement and Kyvsgaard 2014: 18). In other words, one important finding was that a significant number of the people who become members of outlaw biker groups later leave. Even though the vast majority leave of their own volition, increasing the number who leaves should be a strategic goal both because it will reduce their criminal activities and because it might weaken the group.

If several members leave an outlaw motorcycle club at the same time as others are serving prison sentences, this can easily give rise to a situation where the number of active club members falls below a critical mass and threatens the club's very existence. Some motorcycle clubs are closed down or "frozen" by their parent organisation because they do not have enough free, active members of adequate quality to run the activities.

Another form of exit on a group level is when the motorcycle club collectively decides to downgrade its links with an outlaw motorcycle club. There are examples of diamond support clubs returning their diamond patches to the Hells Angels to mark that they no longer want to be regarded as an official Hells Angels support club. The Aviators motorcycle club in Mandal, Norway handed its cut-off diamond patches to the mayor's office after the local authority and police had made it very clear that these sorts of ties to the Hells Angels would have negative consequences for the club. ${ }^{58}$

Important measures in a group level exit strategy aimed at getting entire clubs to downgrade their ties to the Hells Angels or other outlaw motorcycle clubs can include making clear the consequences of the choices the club is making. The police and local authorities could, for example, communicate that they would be far more accommodating and positive when it comes to facilitating motorcycle rallies and similar events, including by granting temporary alcohol licences, if ordinary motorcycle clubs are behind them, while diamond support clubs and outlaw motorcycle clubs run a far greater risk of being refused such advantages. ${ }^{59}$

On an individual level, providing direct assistance to people who want to get out of violent and criminal groups may be a key measure. Some projects are directly aimed at people who leave criminal gangs. There are a number of such exit or rehabilitation projects in Scandinavia with different organisational links and methods.

\footnotetext{
${ }^{57}$ Research on defectors from gangs (Pyrooz and Decker 2011) has found that the vast majority who break out of gangs do not do so through organised programmes, but do it on their own with the help and support of family and others in their social network.

$58 \mathrm{http} / / /$ www.p4.no/story.aspx?id=406686 (accessed 27.01.2016).

${ }^{59}$ One example of this is the Twin Eagles HD motorcycle club in Farsund, Norway, which was refused a mobile alcohol license for a spring rally because it was a diamond support club that openly supported the Hells Angels. http://www.lister24.no/nyheter/N-Farsund/Foler-seg-motarbeidet-30111.html (accessed 22.10.2012, now requires subscription).
} 
The most ambitious effort in Scandinavia is "Exit for bikers and gang members" in Denmark, ${ }^{60}$ which targets those wishing to leave both outlaw motorcycle clubs and other criminal gangs (whose members generally have immigrant backgrounds). ${ }^{61}$ Exit, which was officially started by a government policy decision in April 2011, is a partnership between the Danish Prison and Probation Service, the police and local authorities.

If you have strayed from the straight and narrow and ended up as a member of a gang or biker grouping, but are motivated to live a life outside the milieu and without crime, then society should be able to provide a way out. (Justitsministeriet 2011, p. 3) ${ }^{62}$

One important element of the Danish effort is the establishment of local Exit units in all police districts with close ties to the senior leadership of the police and local authority. The Exit units typically consist of a police officer, someone from the Danish Prison and Probation Service and one or more people from local authority agencies with responsibility for labour and welfare services. However, how they are organised can vary significantly from police district to police district and from local authority to local authority. In some places Exit is a police-based project, while in others it is a local authority-based project. Exit efforts are, according to the framework model, directed specifically at people who are registered as having ties to "biker or gang groupings" in the Danish police's investigation support database (PED). A total of 1759 bikers or gang members were registered in Denmark in January 2014. ${ }^{63}$ But some Exit units also offer help to people on the periphery of gangs without them necessarily having to be registered in PED (Pedersen 2014a, b, c: 8-9).

The criteria for someone in the target group being admitted to an Exit programme is that the person has a genuine desire to leave the criminal milieu and is capable of completing an Exit programme. Suitability and motivation are therefore assessed through a screening process before any Exit collaboration agreement is entered into. As a rule, it is the candidates themselves who contact the authorities and ask to be admitted. If the person is found to be suitable, an agreement will be signed that describes the measures the person needs, the measures that can be offered and what the participant must do. The needs and measures may involve relocating to another part of the country, work or work training, drug rehabilitation, psychological follow-up,

\footnotetext{
${ }^{60}$ In Denmark the term "rocker" is used to refer to the biker subculture, which is often synonymous with the outlaw motorcycle clubs. The Danish term "bande" means "gang" but carries even stronger connotations of a group involved in crime.

${ }^{61}$ The description of the Danish Exit effort for bikers and gang members is based on a report written by Maria Libak Pedersen (2014a). The report describes the framework model and its implementation, while subsequent reports will evaluate the results of this effort when it has had time to work for a few years.

62 http://www.justitsministeriet.dk/nyt-og-presse/pressemeddelelser/2013/ny-rocker-og-bandepakke-fast-grebom-banderne

${ }^{63}$ It should be noted that the Danish Police treat "bikers" and "gangs" as a single phenomenon, or at least two milieux that are strongly intertwined. This is partly because they are in conflict with each other and are competing for some of the same criminal markets and partly because they have strong common features. By comparison, the Norwegian police are far more likely to regard outlaw motorcycle clubs as a different phenomenon to ethnic minority gangs, and use different strategies for them. Besides, there have been no conflicts in Norway between these two categories as there have been within the categories, for example between the Hells Angels and the Bandidos, and between the different Pakistani gangs.
} 
grants to remove tattoos and help with finding housing. In some cases, there may also be a need for protective measures and a new identity in order to escape threats from former friends and old enemies (Pedersen 2014a, b, c: 11ff). The needs of the people who are admitted to Exit vary greatly. Some are almost self-reliant, while others need more extensive security measures and intensive psychological treatment. One key measure is that they are being assigned a regular mentor who can help and guide them through the process and who is also available outside normal office hours.

The goal of the Danish Exit effort is for clients of Exit to (1) cease committing biker/ gang related crime, (2) cease interacting with the biker/gang milieu, (3) change their lifestyle and start a new life outside the biker/gang milieu, and (4) stop exhibiting negative and strongly controlling behaviour in relation to others (Pedersen 2014a, b, c: 14). Another goal is for them to live safe from any threats from their former milieu and have a stable life with a home and job that makes them as self-sufficient as possible (Pedersen 2014a, b, c: 12-14).

An exit programme with a more limited format and target group was established by the Norwegian city of Trondheim in 2009. The project was aimed at 11 young adults who had been responsible for a lot of violence and were part of a large network of friends. Four of these were participants in AK81, ${ }^{64}$ a street crew that had just been established by the Hells Angels in Trondheim. The goals were to get the young people to cease their violent activities and leave the criminal milieu/network of which they were a part, prevent further recruitment to the Hells Angels and prevent them from being used to do the Hells Angels' dirty work. The project, "18-23", was a partnership between the child welfare services, the health and welfare agency, the labour and welfare administration, the correctional service and a number of other institutions. The young men were all known to the child welfare services and had more than 400 registered violent incidents between them when the project started. However, participating in AK81 provided those who joined with much of what their childhoods had lacked: a strong male role model, leadership, specific tasks that they mastered and the resulting status. ${ }^{65}$

Each of the participants in the project was assigned a staff member from the health and welfare agency who, through personal follow-up, contributed to finding measures that would help and alternative arenas in which they could succeed. Some needed help finding housing, others needed help with the labour and welfare administration, managing their finances and medical treatment. They could also get assistance when they met the police, mediation boards or with completing their sentence.

As previously mentioned, AK81 in Trondheim disbanded during the project period because the president of Hells Angels Trondheim, who was behind AK81, was imprisoned in a major drug case and thus put out of play. The Hells Angels' grip on the young men therefore weakened, and this in turn resulted in two of the young men in the project switching from AK81 to the Mongols MC. They were imprisoned in 2012 for serious violence after an internal showdown. The project continues to work with them while they are serving their sentences. The other two participants in AK81 got out of the milieu and things have worked out better for them, which is also the case with the

\footnotetext{
64 The abbreviations "AK81" or "AKT81" stand for the Norwegian slogan meaning "Always Ready Trondheim Hells Angels". Both abbreviations have been used.

${ }^{65}$ Based on the project report provided here: http://wikiprevent.no/95/item (accessed 27.01.2016).
} 
other project participants who did not have ties to the outlaw biker scene. They have not necessarily become completely law-abiding, but their violent criminal activities have decreased significantly and they are no longer regarded as potentially dangerous and violent. After AK81 disbanded, Trondheim had no new relevant candidates from the outlaw biker groups who could participate in the project. But the project continues along the same lines, where the target group is young men heavily involved in crime. ${ }^{66}$

Another type of project for people leaving gangs is run by people who have a background from criminal groups, and who have been through the process of breaking out of a gang and have managed to stand on their own two feet. They have started their own projects to help others who are at the beginning of such a process, based on the theory that others might benefit from their experiences and that they have a level of street credibility that the public welfare system does not possess. One example of this is the Danish TGM project (which stands for the Danish for "Former Gang Members"), ${ }^{67}$ which is headed by a former member of the Bandidos. A project for those who want to leave gangs called "Passus" has been established in the Fryshuset youth centre in Stockholm. This is based on the same model as the exit project for people disengaging from the white power movement, where former participants in the extreme right-wing milieux play key roles. ${ }^{68}$ The Swedish Exit project has been in operation since 1998 and has received great recognition for its work. Sweden also has the KRIS project, which stands for the Swedish for "Criminals Return Into Society", which supports people on their way out of prison and back into society based on project workers' own experiences. ${ }^{69}$ In Norway, "WayBack" is based on a similar model, where former criminals help others back to a law-abiding life. ${ }^{70}$

Opinions differ on whether public agencies with their social work expertise, voluntary organisations consisting of people with backgrounds from such milieux or family and social networks are the most suitable actors to help people who want out of these heavily criminal milieux. ${ }^{71}$ One problem with many of the self-help groups is that not all of the helpers have achieved sufficient distance from their own criminal pasts and end up back in crime and prison themselves. One of the important lessons learned from the Swedish Exit programme is that the mentors must have spent several years outside the extremist milieu and come to terms with their extremist past before they can get involved in the work of helping others who want to leave (Christensen 2014, 2015).

The target group for rehabilitation and exit measures are people who participate in, or who have participated in, criminal gangs and groups, that is the problem group (indicated prevention). However, the dividing line between this and what you could call the risk group is not always easy to draw in practice. The local versions of the Danish Exit programme sometimes have different practices when it comes to who can be

\footnotetext{
$\overline{66}$ The description of the "18-23" project was taken from the Norwegian National Police Directorate's handbook (2014, p. 23), which in turn is based on the following report: http://wikiprevent.no/95/item (accessed 27.01.2016).

${ }^{67}$ Link to the website of TGM (Former Gang Members): http://www.tbm-tbm.dk/info.html.

${ }^{68} \mathrm{See}$ http://passus.fryshuset.se/ and http://exit.fryshuset.se/english/ (accessed 27.01.2016).

${ }^{69} \mathrm{http}: / / \mathrm{kris}$.a.se/in-english/ (accessed 20.01.2016).

70 www.wayback.no (accessed 20.01.2016). WayBack helps former convicts in general, but many have gang affiliations.

${ }^{71} \mathrm{http}$ //www.bt.dk/krimi/fagfolk-kommunerne-ikke-gearet-til-at-hjaelpe-bandemedlemmer (accessed 20.01.2016). For information about the local authority Exit project in Copenhagen, see the evaluation: http://subsite.kk.dk/ /media/8389EA3783AD472E8E593BCB98FB3828.ashx (accessed 20.01.2016).
} 
admitted to the programme. Some local Exit units have admitted people who exhibit clear signs of gang membership even if they are not registered in the Danish police gang database (PED), and some accept individuals who have not yet become bikers/ gang members but are expected to become recruits (described as a "pre-entry exit programme"). There is a risk that expanding the target group like this to include people who belong to the risk group will dilute the efforts of exit programmes (Pedersen 2014a, b, c: 17). Moreover, the vast majority of the primary target group are adults (over 18), while some of those in the risk group are teenagers.

Programmes aimed at getting participants in criminal gangs to break with their criminal milieux have obvious major benefits for both individuals and society. It has been calculated in Sweden that a member of a criminal gang who lives in such a milieu for 15 years generates social costs of around SEK 23 million, or about USD 3,2 million (Lundmark-Nilsson and Nilsson 2012: 89-90, see also Bjørgo 2016: 106). Successfully rehabilitating such a person both saves money and prevents suffering. If you manage to get a lot of people to leave criminal gangs, it may also help reduce the size of the groups as well as their activities and potential for violence, and thus also the problem of crime itself.

The exit strategy also has its limitations and costs. While such comprehensive efforts cost a substantial amount of money, relatively few full patch members of outlaw motorcycle clubs break out of the milieu (more leave the support groups). With the exception of the Danish study (Klement and Kyvsgaard 2014) we lack systematic knowledge about member turnover in outlaw motorcycle clubs and how many actually leave. More research is obviously needed here. The experiences so far from the Exit programme for biker and gang members in Denmark provide grounds for optimism that such disengagement and rehabilitation programmes can play an important role in helping people break out of a criminal milieu and return to a more normal lifestyle. After three years of operation, there has been far greater interest than expected from outlaw bikers to join the Exit programme (Rigspolitiet 2015). The upcoming evaluation of the results of the Danish Exit project will hopefully show whether or not the effects are living up to expectations and are worth the cost and effort. If they are, such rehabilitation exit projects could become a key measure in reducing the organised crime that originates from outlaw motorcycle clubs and other criminal gangs.

\section{Conclusions}

This article has applied a generic and holistic model of crime prevention to reduce and handle crime originating from outlaw motorcycle clubs. The relationship between participation in such clubs and actual criminal behaviour is complex as far from all members are actually involved in serious crime, although a considerable proportion is, and the clubs tolerate and sometimes even facilitate criminal involvement. Thus, appropriate responses need to be complex and measured as well. A repressive criminal justice approach based on deterrence and incapacitation should be supplemented by more nuanced strategies to reduce recruitment to outlaw MC clubs and criminal activities, counter acceptance of criminal values and behaviours, disrupt criminal acts before they are committed, reduce opportunities for criminal activities, reduce profits from crime, reduce harm, and facilitate disengagement from outlaw motorcycle gangs. 
A number of examples have been provided for how these crime preventive mechanisms can be translated into practical measures implemented by a wide range of preventive actors.

Funding This research has been funded by the Norwegian Police University College (as salary from employer) and with a grant from the Fulbright Foundation in Norway as a visiting scholar at John Jay College of Criminal Justice, City University of New York (date issued: May 7, 2014, no award number).

\section{Compliance with ethical standards}

Conflict of interest There are no conflicts of interest.

Ethical approval This article does not contain any studies with human participants performed by the author.

Open Access This article is distributed under the terms of the Creative Commons Attribution 4.0 International License (http://creativecommons.org/licenses/by/4.0/), which permits unrestricted use, distribution, and reproduction in any medium, provided you give appropriate credit to the original author(s) and the source, provide a link to the Creative Commons license, and indicate if changes were made.

\section{References}

Barker T (2005) One percent biker clubs: a description. Trends in Organized Crime 9(1):101-112

Barker T (2007) Biker gangs and organized crime. Anderson Publishing, Newark

Barker T (2011) American based biker gangs: international organised crime. Am J Crim Justice 36(3):207215

Beare ME (ed) (2003) Critical reflections on transnational organized crime, money laundering, and corruption. University of Toronto Press, Toronto

Bjørgo T (2013) Strategies for preventing terrorism. Palgrave Macmillan (Palgrave Pivot series), London

Bjørgo T (2014) Policing demonstrations in Oslo: a total change of approach. European Journal of Policing Studies 2(/1):130

Bjørgo T (2016) Preventing crime: a holistic approach. Palgrave Macmillan, London

Bjørgo T, Carlsson Y, Haaland T (2005) Conflict processes between youth groups in a Norwegian City: polarization and revenge. European Journal of Crime, Criminal Law and Criminal Justice 13/1: 44-74

Christensen TW (2014) Adding a Grey tone to a black and white world view - how role models and social encouragement can lead former right-wing extremists to transform their identity. In: Rieker P (ed) Hilfe zum Ausstieg? Ansätze und Erfahrungen professioneller Angebote zum Ausstieg aus rechtsextremen Szenen. Weinheim/Basel, Beltz Juventa

Christensen TW (2015) How extremist experiences become valuable knowledge in EXIT programmes. Journal for Deradicalisation, Summer/15, no. 3 http://journals.sfu.ca/jd/index.php/jd/article/view/18

Clarke RV (1997) Situational crime prevention: successful case studies, 2nd edn. Criminal Justice Press, Monsey

Cohen S (1973) Folk devils and moral panics. Paladin, St Albans

Decker SH, Pyrooz DC (2015) "I'm down for a Jihad": how 100 years of gang research can inform the study of terrorism, radicalization and extremism. Perspectives on Terrorism 9(1):104-112

Edwards A, Gill P (2003) Transnational organised crime: perspectives on global security. Routledge, London

Justitsministeriet (2011) En Vej Ud: Rammemodel for exit-programmer til bande- og rockermedlemmer der ønsker at bryde ud af miljøet. København, Justitsministeriet

Kennedy DM (2009) Deterrence and crime prevention: reconsidering the prospect of sanction. Routledge, London

Klement C, Kyvsgaard B (2014) Flowet i rocker/bandemiljøerne. Justitsministeriets Forskningskontor, København http://www.justitsministeriet.dk/sites/default/files/media/Arbejdsomraader/Forskning/Forskningsrapporter/2014 /Flow\%20rapport.pdf 
Klement C, Kyvsgaard B, Pedersen A-JB (2010). Rockere, bander og risikofaktorer. Justitsministeriets Forskningskontor, Rigspolitiet, October 2010

Korsell L, Larsson P (2011) Organized crime the Nordic way. Journal of Crime and Social Justice 20:519-554

Krysko K (2013) Kerri on: a memoir of a hells angel ex-wife. Friesen Press, Victoria

Lauchs m, Bain A, Bell P (2015) Outlaw motorcycle gangs: a theoretical perspective. Palgrave Macmillan (Palgrave Pivot series), Basingstoke

Lavigne Y (1996) Hells angels: into the abyss. Harper, New York

Lundmark-Nilsson E, Nilsson I (2012) Vänd dem inte ryggen: Socioekonomisk analys av destruktiva subkulturer. OFUS \& Fryshuset, Stockholm

Matter P, Omodt C (2014) Breaking the code: a true story by a hells angel president and the cop who pursued him. The Real Deal, LLC

Pedersen ML (2014a) Exit-indsatser for rockere og bandemedlemmer. En kortlægning af tiltag under rammemodellen. Justitsministeriets Forskningskontor, København April 2014

Pedersen ML (2014b) Gang joining in Denmark: prevalence and correlates of street gang membership. Journal of Scandinavian Studies in Criminology and Crime Prevention 15(1):55-72

Pedersen ML (2014c) Veje ind i og veje ud af rocker- og bandemiljøer. En interviewundersøgelse. Justitsministeriets forskningskontor, København Sept. 2014. http://justitsministeriet. $\mathrm{dk} /$ sites/default/files/media/Arbejdsomraader/Forskning/Forskningsrapporter/2014/Veje \%20ind\%20i\%20 og\%20veje\%20ud\%20af.pdf

Politidirektoratet (2011) Politiets bekjempelse av kriminelle MC-gjenger i perioden 2011 til 2015. Politidirektoratet, Oslo

Politidirektoratet (2014) Forebygge og bekjempe kriminalitet fra énprosentmiljøet og kriminelle MC-gjenger Håndbok for politi og kommunale myndigheter. Politidirektoratet, Oslo POD-publikasjon 2014/02. https://www.politi.no/vedlegg/lokale_vedlegg/politidirektoratet/Vedlegg_2456.pdf

Pyrooz DC, Decker SH (2011) Motives and methods for leaving the gang: understanding the process of gang desistance. J Crim Just 39(5):417-425

Rigspolitiet (2013) Rockere og bander. København, Rigspolitiet, p 2012 https://www.politi. dk/NR/rdonlyres/A80FE0FB-894C-45D2-A408-2D9D525A1ECB/0/rockerbanderappport2012.pdf

Rigspolitiet (2014) Rockere og bander. København, Rigspolitiet, p 2013 http://www.mynewsdesk. com/dk/rigspolitiet/documents/rocker-og-bander-2013-35860

Rigspolitiet (2015) Rockere og bander 2014. København, Rigspolitiet https://www.politi.dk/NR/rdonlyres/54 AC93D2-95A6-401D-938B-FD479F76A30C/0/Rockereogbander2014.pdf

Rostami A, Leinfelt F (2012) The Stockholm gang intervention and prevention project (SGIP): introducing a holistic approach to gang enforcement. In: Esbensen F-A, Maxson CL (eds) Youth gangs in international perspective: results from the Eurogang program of research. Springer, New York

Sageman M (2004) Understanding terror networks. Pennsylvania University Press, Philadelphia

Stubberud R, Jensen E (2011) Alt starter og avsluttes med et håndtrykk - Dialog med gjengstrukturer, erfaringer, resultater og råd. Oslo Politidistrikt. https://www.politi.no/vedlegg/lokale_ vedlegg/oslo/Vedlegg_1548.pdf, Oslo Accessed 14 Mar 2013

Tilley N (2009) Crime Prevention. Willan Publishing, Cullompton/Portland

Wierup L, Larsson M (2007) Svensk maffia: en kartläggning av de kriminella gängen. Nordstedts, Stockholm Wierup L, Olson D (2012) Helvetet inifrån - femton år i Sveriges största brottsorganisation. Reporto Förlag, Stockholm

Wolf DR (1991) The rebels: a brotherhood of outlaw bikers. University of Toronto Press, Toronto 